\title{
Foreign Aid Allocation Tactics and Democratic Change in Africa
}

\author{
Simone Dietrich* \\ Joseph Wright ${ }^{\dagger}$
}

May 2014

\begin{abstract}
Over the past two decades, donors increasingly link foreign aid to democracy objectives in Africa. This study investigates whether and how foreign aid influences specific outcomes associated with democratic transition and consolidation. Using an instrumental variables approach for the period from 1989 to 2008, we show that economic aid increases the likelihood of transition to multiparty politics, while democracy aid furthers democratic consolidation by reducing the incidence of multiparty failure and electoral misconduct. However, we find little evidence that either economic or democracy aid influences opposition support in multiparty elections. These findings have implications for understanding how donors allocate aid and the political consequences of foreign assistance in Africa.
\end{abstract}

*University of Missouri, corresponding author. Replication materials can be found at: www. simone-dietrich.com.

${ }^{\dagger}$ Pennsylvania State University 
Since the end of the Cold War, a consensus in the international donor community argues that democracy is an integral part of development efforts. Some foreign aid proponents suggest that without aid "the global democratic revolution cannot be sustained" Diamond $(1992,45)$. While a normative approach to democracy promotion emphasizes the importance of civil and political rights for human freedom (Sen, 1999), the instrumental perspective promotes democratization based on the premise that democratic institutions incentivize governments to increase spending on welfare outcomes (Stasavage, 2005; Huber, Mustillo and Stevens, 2008; Harding and Stasavage, 2014). In the 1990s and 2000s, donors contributed hundreds of billions of dollars of aid worldwide, with the largest proportion flowing to sub-Saharan Africa. Goldsmith (2001) and Dunning (2004) show that foreign aid positively influences democracy in recipient countries, yet neither study explores the causal mechanisms linking aid and democratic change. ${ }^{1}$ Our contribution examines possible causal mechanisms by looking at the same region: Africa.

Sub-Saharan African cases are useful for testing arguments linking aid to democracy because in the past two decades most countries in the region adopted multiparty politics. This not only marked a shift in power in many countries but also provides much of the evidence for the global wave of democratic transitions since the end of the Cold War. From 1989 to 2008, roughly half of all democratic transitions in the world occurred in sub-Saharan Africa; and countries with a variety of autocratic regimes - including personalist rule, military dictatorships, and one-party states - experienced transitions. ${ }^{2}$ However, the shift to multiparty politics did not lead to a wave of consolidated democracies (Posner and Young, 2007; Cheeseman, 2011). Indeed, in the twenty years to 2008 incumbent leaders left power only eight times after losing elections under established multiparty regimes. ${ }^{3}$ Thus for many countries in the region, the introduction of multiparty politics

\footnotetext{
${ }^{1}$ Other research suggests that aid has pernicious effects on democratic development (Bueno de Mesquita and Smith, 2009; Djankov and Reynal-Querol, 2008; Brautigam and Knack, 2004).

${ }^{2}$ Data from Cheibub, Gandhi and Vreeland (2010) show that 24 of 47 transitions to democracy took place in sub-Saharan Africa.

${ }^{3}$ These are: Benin 2001, Cape Verde 2001, Ghana 2000, Guinea-Bissau 2000, Kenya 2002, Madagascar 1996, Mali 2002, and Senegal 2000.
} 
did not lead to strong democratic institutions. This variation in post-transition democracies spurred a vibrant debate about the determinants of democratic survival and consolidation. This paper examines how external assistance influences transition to and consolidation of democracy, and in doing so employs multiple measures to capture distinct aspects of consolidation.

We examine two mechanisms through which aid might influence democracy in recipient countries: (1) donors attaching political reform conditions to economic aid; and (2) donors directly investing in democracy promotion through activities aimed at strengthening governance institutions and civil society. These mechanisms focus on different categories of aid - economic aid and democracy assistance - and have implications for distinct political outcomes. For example, donor pressure to hold elections may be more likely to push a transition to multiparty regimes but may not influence electoral support for the opposition or electoral misconduct. Investing in civil society organizations, in contrast, is unlikely to operate through economic aid but has implications for whether democracy assistance improves electoral support for opposition parties.

To date, however, most research on foreign aid and political development tests how aid influences broad indices of democracy from sources such as the Polity index or Freedom House. While useful for many purposes, these measures are unable to distinguish particular aspects of democratic transition and consolidation. Further, only a handful of studies look at how the political effect of economic and democracy aid may differ. In this paper, we unpack the hypothesized mechanisms linking aid to democracy by examining multiple dimensions of democratic political change - including transitions to and from multipartyism as well as electoral misconduct and electoral support for the opposition - and test how different broad categories of aid influence these outcomes.

We show that donors pursue a strategy of incumbent-led democracy promotion in Africa when dealing with dictators and democrats. While donors use aid to propel top-down democratic reforms both prior to and after transitions to multiparty regimes, they do so by pursuing different tactics. When dealing with dictators, donors employ economic development assistance to buy political reform that is largely procedural in nature, such as legalizing opposition parties and holding multiparty elections. While these reforms are sufficient for "formal" transitions to multiparty regimes, they may not necessarily alter the balance of power between the incumbent and opposi- 
tion groups. Nor do such reforms necessarily require elites to change their political practices. This makes transitions relatively cheap for many dictators.

Donors dealing with democrats in post-transition contexts influence democratic development through targeted investment in democracy-related activities rather than via conditionality attached to economic aid. Further, we show that donors are most successful at influencing democratic consolidation outcomes by investing in governance but find little evidence that democracy aid targeting civil society organizations influences election outcomes or incumbent electoral behavior.

Our findings have implications for democracy promotion and international actors who attempt to influence the process of democratic transition and consolidation. By shedding light on the causal pathways through which foreign aid changes political outcomes in recipient countries, we show both the areas where foreign actors can promote democratic outcomes and the limits of such strategies. We find that while economic aid can buy relatively cheap multiparty transitions, democracy aid can help consolidate multiparty regimes but rarely influences the political balance between incumbents and the opposition in these countries. Our findings illustrate the value of differentiating aid categories and precisely measuring the political outcomes that most closely match the causal story. An emerging literature links foreign aid to many important outcomes such as civil conflict, terrorism, and human rights (Nielsen et al., 2011; Savun and Tirone, 2012). Future research in these areas will benefit from examining different categories of foreign aid to pinpoint the mechanisms at work.

\section{Foreign aid and democracy}

Studies linking aid to democracy provide a mixed picture. Some argue that donors leverage their economic power by attaching political reform conditions to aid packages. Using conditionality to 'buy reform' requires that donors can credibly withdraw or redirect aid when recipient government do not comply (Burnell, 1997; Dunning, 2004). This mechanism is often associated with transitions to multiparty politics, particularly in the 1990s. For example, Resnick (2013) highlights the crucial role of donor leverage in Malawi's first multiparty election in 1993; and Handley (2008) argues that donor pressure motivated Ghana's President, Jerry Rawlings, to "consider liberalization of 
the political regime and a return to constitutionalism." Citing this leverage mechanism, some find a link between aid and democratic transitions only during the post-Cold War period when donors' threat of aid withdrawal was most credible (Dunning, 2004; Wright, 2009; Bermeo, 2011).

Others posit that democracy assistance influences democracy through a direct investment channel, targeting either incumbent governments (by focusing on budgeting procedures, bureaucratic competence, and judicial and legislative independence) or democratizing agents in civil society (by focusing on particular organizations that typically stand outside the recipient government). Citing the investment mechanism, some studies find that democracy assistance increases the level of democracy, as measured by broad democracy indicators (Finkel, Pérez-Lián and Seligson, 2007; Scott and Steele, 2011). Bush (Forthcoming) explores the nature of civil society assistance and finds that, over time, democracy promotion has become more "tame" as international NGOs increasingly select more regime-compatible projects to guarantee future funding.

We contribute to this debate by presenting an argument that differentiates between mechanisms of democracy promotion (economic and democracy aid) and distinct delivery channels of democracy assistance (donor-to-government and donor-to-civil society). We specify when aid contributes to democratic outcomes and in doing so explain why donors successfully promote horizontal accountability but have fallen short in improving vertical accountability.

\section{Donor tactics and democracy promotion}

Transitions to multiparty politics and democratic consolidation represent different stages of democratic development, which trigger different donor tactics. Multiparty transitions require incumbents to focus on a targeted event - elections with opposition parties - while consolidation requires more complex political changes. In the 1990s, donor demands for elections and minimal procedural reforms converged around election day. For example, Brown (2011) provides evidence from interviews with donors working in countries as diverse as Rwanda, Kenya, and Malawi that aid recipients heard a consistent reform message emphasizing multiparty elections; while Crawford (2001) notes that donor coordination was crucial for leveraging multiparty elections across the continent.

After transitions, however, there is less donor consensus on the specific goals of democracy pro- 
motion. Not all donors agree on how to advance democratic consolidation, especially when donors face trade-offs among consolidation, development, and stability in recipient countries (Brown, 2011). While the pursuit of each of these policy goals may be desirable, they are not always compatible. Since the mid-1990s donor governments have emphasized improving service delivery and development, as is evident in the Millennium Development Goals. Donors fear that withholding foreign aid in response to lackluster progress in democratic consolidation may lead to far worse outcomes, such as instability and conflict (Resnick, 2013). What is more, key principles of the international aid architecture, such as country-ownership, create donor ambivalence about criticizing recipients' commitment to democratic consolidation.

In light of these tensions, donors should be less forceful in promoting democratic consolidation efforts than transitions to multipartyism. Instead of relying on threats to withdraw economic assistance, as was often the case prior to multiparty transitions, donors increasingly pursue more targeted tactics by earmarking aid for specific democracy promotion activities. The top panel of Figure 1 shows that while economic aid to sub-Saharan African countries dipped in the 1990s, democracy aid increased throughout the past two decades with largest bump after 1998 .

Further, once countries transitioned to multiparty regimes, donors substantially increased democracy aid - both to the government and to civil society groups - with no corresponding economic aid dividend. The bottom, left panel of Figure 1b shows that democracy aid increased by nearly 20 percent in the three years after a multiparty transition relative to the pre-transition period. The bottom, right panel shows that the collapse of multiparty regimes also yields large increases in democracy assistance. Economic aid, on the other hand, remains at very similar levels pre- and post-transition, but drops considerably once a multiparty regime collapses.

When dealing with dictators prior to multiparty transitions, donors prioritize economic development assistance as a tool to extract political reform concessions. The political conditions attached to economic aid are often relatively minimal in scope and procedural in nature, consisting of items such as introducing executive term limits, legalizing opposition parties, and holding elections. While such reforms are often sufficient for "formal" transitions to democracy, they may not necessarily alter the political balance in the country in significant ways or require elites to change 
their political practices. For instance, Tanzania's shift to a multipartyism in the 1990s represented a formal break from the past. Yet, the incumbent Chama Chama Mapinduzi (CCM) managed the transition and post-transition environments to its advantage, resulting in uninterrupted dominance over opposition parties (Tripp, 2012). During the transition to democracy in Ghana, the ruling National Democratic Congress (NDC) stacked transition bodies with pro-NDC members and kept the election timetable "closely guarded," while the opposition dismissed the introduction of multiparty politics as "transitions without change" (Gyimah-Boadi and Yakah, 2013, 1-2). In both cases, donors primarily focused their demands on holding of elections. Even though the advent of multipartyism may not substantially alter politics in aid recipient countries, as these case illustrations suggest, there is nonetheless a clear empirical expectation that follows from the leverage argument: economic aid should increase the likelihood of multiparty transitions in recipient countries.

Once countries transition to multiparty regimes, democracy promotion initiatives aim to consolidate democratic rule by strengthening both horizontal and vertical accountability. Donor investments in judicial independence, legislative effectiveness, and anti-corruption commissions, for example, may check abuses by government officials, while donor aid targeting civil society groups and political party development may improve vertical accountability. In a post-transition context, donors are more apt to focus on influencing democracy through targeted investment in horizontal accountability. These investments emphasize strengthening state capacity, which is direclty compatible with economic development goals.

Further, whereas the leverage argument focuses on the relationship between donors and recipient governments, investments in democracy aid target two types of actors in recipient countries: the incumbent government and civil society groups, with the latter sometimes including opposition political parties. The strategies donors choose in attempts to influence recipient country politics have implications for how and to whom donors deliver aid. For example, Dietrich shows that donors increasingly bypass the government and give aid directly to non-state actors in poorly governed countries to prevent the capture of aid through corrupt officials or inefficient state institutions Dietrich $(2013,2014)$. Further, by strategically targeting sectors where recipient compliance with aid project goals is relatively easy, donors can provide recipient governments with a stronger incentive 
to comply and thereby improve aid effectiveness Dietrich (2011).

Who receives democracy aid, in turn, has implications for its political consequences. Democracy aid projects aimed at increasing state capacity target recipient governments and may therefore increase incumbent strength. For example, an aid project such as Canada's $\$ 17$ million investment in Mali's Justice Development Project in 2010 attempts to strengthen the credibility, effectiveness and accessibility of the national justice system to citizens. The recipient government - in this case the Ministry of Justice - was the direct recipient of democracy aid and implemented the program. Democracy aid that targets recipient governments may strengthen the incumbent regime by improving state capacity in predictable ways and thus increasing the regime's legitimacy vis-a-vis citizens. A case study of donor involvement in Mali by Van de Walle (2013) highlights this point and goes even further by suggesting that the focus of aid resources on the central governments provided a clear incumbency advantage vis-a-vis civil society and political parties. Evidence from Malawi (Resnick, 2013) and Zambia (Rakner, 2013) suggests a similar dynamic where donors contributed to improving electoral management and electoral fairness but executive dominance remained largely unchallenged. Recipient governments therefore have an incentive to implement democracy aid projects, but only when donor goals such as improving state capacity or service delivery do not threaten the ability of the incumbent to retain power.

In contrast, aid efforts that directly target civil society and opposition forces largely bypass the incumbent regime. ${ }^{4}$ These projects should strengthen opposition groups and thus weaken incumbent leaders. For instance, Denmark's $\$ 4$ million support for grass-roots mobilization efforts in Karamoja, Uganda, bypassed the incumbent government entirely and instead was implemented by a local non-governmental organization, Uganda Action for Social Change. By providing organizational and material resources to opposition groups, this bottom-up democracy aid can help level the playing field between incumbents and the opposition. Case study evidence from Benin (Gazibo, 2013) and Ghana (Gyimah-Boadi and Yakah, 2013) show that donor funding of civil society and opposition groups can significantly bolstered non-state actors' capacity to increase voter-turn out thus directly affecting the electoral playing field in a series of successive, competitive elections. In

\footnotetext{
${ }^{4}$ In some contexts, however, incumbent governments may infiltrate NGOs.
} 
these types of democracy promotion projects, donors select either the government or groups outside the government as primary recipients of aid. This selection, in turn, has implications for both the causal mechanism linking aid to democratic consolidation outcomes and the direction of the expected relationship: democracy aid to the government strengthens the incumbent while democracy aid to civil society weakens incumbent power.

Further, some outcomes associated with democratic consolidation, such as the duration of multiparty regimes, do not necessarily threaten the incumbent's hold on power, as the Tanzanian case illustrates. In contrast, other outcomes, such as stronger electoral support for the opposition, directly threaten government survival. Standard measures of democracy derived from the Polity or Freedom House, however, cannot distinguish between these. We therefore use measures of democratic consolidation that may entail both threats to incumbents and those that do not. This discussion suggests three expectations:

- Transition hypothesis: Economic aid increases the likelihood of multiparty transition

- Consolidation hypothesis (a): Democracy aid to recipient governments furthers democratic consolidation that does not threaten incumbents

- Consolidation hypothesis (b): Democracy aid to civil society furthers democratic consolidation that may threaten incumbents.

\section{Research Design}

\section{Democratic transition and consolidation}

We define multipartyism as the existence of an opposition party in an elected legislature. Minimally, this entails universal suffrage, ${ }^{5}$ an elected legislature, legal opposition parties, and at least one party outside the regime front with seats in the legislature. This definition of multipartyism excludes regimes that allowed opposition parties but never held an election to place them in a legislature (e.g. the former Zaire from 1992-1997). It also says nothing about electoral fairness or civil liberties,

${ }^{5}$ The suffrage rule allows the start of multiparty politics in South Africa (1994) and Zimbabwe (1980) after the end of restricted suffrage rule. 
and thus groups together countries with relatively non-violent and free elections (e.g. Botswana 1999 and 2004) with countries which sometimes have unfair and violent multiparty elections (e.g. Kenya 1997 and 2007).

While multipartyism may be a minimal condition for democracy (Cheibub, Gandhi and Vreeland, 2010), two features of multiparty transitions are relevant for assessing the influence of foreign aid. First, donors can relatively cheaply and objectively identify whether multiple parties compete for and hold positions in an elected legislative body. Second, the introduction of multipartyism need not pose a direct threat to the incumbent regime. We examine how democracy assistance and economic aid influence the advent of 49 multiparty transitions between 1989 and 2008.

Our second measure is the breakdown of a multiparty system. After a country has transitioned to a multiparty regime, it then becomes at risk of reversal. We define multipartyism failure as any one of the following occurring: (a) government change via a coup or replacement of a leader/party during a civil conflict; ${ }^{6}$ (b) institutional change that excludes the opposition, such that opposition parties are illegal or no party outside the regime front is seated in the legislature; or (c) opposition withdraw so that there is no party outside the regime front seated in the legislature.

The March 2003 coup in the Central African Republic, in which the former Army Chief of Staff - François Bozizé - ousted Félix Patassé, is an example of (a). After the coup, Bozizé suspended the constitution and abolished the legislature. Charles Taylor's government in Liberia banned all opposition parties in April 2002, marking the end of multipartyism (b). He had won the prior election (1997) by a large margin while the opposition UP (Johnson-Sirleaf's party) secured only seven seats, marking the start of multipartyism. The next scheduled election (2003) never took place. Finally, all the main opposition parties in Comoros, including the Movement for Democratic Progress (MDP-NGDC) and the former authoritarian party UDZIMA, boycotted the December 1996 legislative elections. The only other party to win legislative seats was allied with the ruling National Rally for Development. This election boycott ended multipartyism (c). ${ }^{7}$

\footnotetext{
${ }^{6}$ Assassination of a leader does not end multipartyism unless this results in an opposition executive taking power or the closing of the legislature.

${ }^{7}$ Table A1 lists the multiparty sample; Table A2 lists the multiparty transition and failure events.
} 
While transitions to and from multipartyism are central to understanding democratic consolidation, neither capture an essential feature of democratic politics: incumbent leaders or parties losing power in elections. Even though the introduction of multiparty politics in the 1990s entailed dislodging many longtime rulers, newly elected leaders only rarely lost at the ballot box, with only eights such instances in the two decades from 1989-2008. With so few data points, it is difficult to directly test how aid influences the prospects of incumbent turnover during this period.

To capture other aspects of democratic consolidation, we use measures of electoral misconduct and opposition vote-share. Electoral misconduct gauges observed incumbent behavior during election years, using an indicator constructed from variables in the NELDA data set: opposition harassment, preventing opposition parties from participating, and violence during elections periods (Hyde and Marinov, 2012). We treat unclear cases as 'no evidence' of misconduct. This codes 30 percent of election years with violence; incumbents prevented opposition participation in 12 percent; and incumbents harassed the opposition in 29 percent. $^{8}$ The dependent variable is coded 1 if any of these types of misconduct occur during an election year; and 0 otherwise. We examine 170 multiparty election years from 1989 to 2008 in 40 countries; 47 percent are coded as misconduct.

While we do not directly test how aid influences electoral turnover under multipartyism, this outcome requires that opposition parties become more competitive in elections vis-a-vis the incumbent. We therefore examine electoral support for opposition parties. If democracy assistance provides resources for democratizing agents to mobilize support for political parties and increase voter-turnout,${ }^{9}$ then we should find evidence linking this category of aid to electoral support for opposition candidates and parties. One criticism foreign leaders level at donors - particularly U.S. democracy assistance programs - points to the possibility that democracy aid hurts incumbents by mobilizing political opponents. In Russia and Venezuela, for example, incumbent leaders accused donors of directly funding opposition parties (Cole, 2007; Herszenhorn and Barry, 2012). Alternatively, aid critics often argue that economic aid helps rulers remain in power by providing non-tax revenues with which they can buy acquiescence if not outright support. This latter argument

\footnotetext{
${ }^{8}$ Some election years were marred by more than one type of misconduct.

${ }^{9}$ NGOs may aid protesters when electoral institutions perform poorly (Boulding, 2010).
} 
implies that aid should bolster electoral support for incumbents.

We measure opposition electoral support as the percentage vote for the largest opposition party (or candidate) as a share of the two-party vote: $\frac{O}{O+I}$, where $O$ is the vote share for the largest opposition party and $I$ is the vote share for the incumbent. This operationalization circumvents issues related to electoral rules and the fragmentation of party systems by focusing on a continuous measure of how close the largest opposition party is to defeating the incumbent at the polls. We concentrate on first round executive elections after a transition to multiparty politics because these contests pit the incumbent party against opposition candidates. ${ }^{10}$

\section{Foreign Aid}

We use foreign aid commitment data from AidData 2.0. We aggregate aid commitments at the recipient country year level and distinguish between economic aid and democracy aid sectors. Economic aid subsumes several sectors, including social, democracy, economic infrastructure and services, domestic production, environment, commodity aid, debt relief, budget support, and emergency relief. Democracy assistance has different purposes and distinct delivery modalities. For instance, democracy and governance aid (DGA) includes projects that directly target policy planning in areas such as fiscal and monetary policy, institutional capacity building, and structural reform. DGA also finances tax assessment procedures, legal and judicial development, and constitutional development. Donors use DGA to support government administration by helping finance civil service reform and government infrastructure. In addition to financing governance-related activities, DGA also flows to non-state development actors including civil society groups and political parties to

\footnotetext{
${ }^{10}$ We examine 84 elections in 34 countries (listed in Appendix Table A4), a smaller number than in last section because the former included legislative elections and first multiparty elections. When there are no direct elections for President, we include parliamentary elections. We exclude: elections where the second round was never held (e.g. Angola 1992); where the results were annulled (e.g. Nigeria 1993); and where no incumbent contests (e.g. Liberia 2005). Appendix Table B4 shows that results are similar if we employ the total opposition vote share (instead of largest opposition vote as share of two-party vote) as the dependent variable.
} 
support community participation, strengthen political accountability, and development. ${ }^{11}$

The top panel of Figure 1 shows that OECD economic aid to sub-Saharan Africa declined in the 1990s but increased in the 2000s, returning to levels that outpaced aid flows at the end of the Cold War. While donors give aid for a variety of reasons, the distribution of aid across different sectors reflects the relative priority donors attach to them. In the past two decades, donors have substantially increased aid earmarked for democracy promotion; and by 2008 we observe a five-fold increase in democracy assistance to Africa. The left panel of Figure 2 shows that the majority of DGA to Africa is direct investment in strengthening state institutions: while DGA rises from 3 percent of total aid in 1990 to over 10 percent in 2008, only a small fraction of democracy promotion activities targets civil society groups. Further, the right panel of Figure 2 shows that the U.S. share of total DGA - which is the focus of studies such as Finkel, Pérez-Lián and Seligson (2007) and Scott and Steele (2011) - remains only a small part of democracy assistance from all donors, particularly after 2000 .

We leverage this disaggregated project-level information on aid delivery channels to buttress the micro-foundations of our argument: donors pursue different goals of democracy promotion by relying on government-led delivery mechanisms. We measure aid as the logged value of the lagged three-year moving average of aid per capita. ${ }^{12}$ The time series for smaller categories of aid, such as democracy and governance aid, show large variation from year to year, so a moving average smooths these trends to better capture inflows over the prior period.

\section{Empirical Approach}

We test the influence of aid at two stages of democratic development: transition and consolidation. The first examines transitions to multiparty regimes; the sample contains 49 transitions in 44 subSaharan African countries. The second examines how aid influences the persistence of multiparty regimes in 44 countries, 16 of which fail. Subsequently we also examine the effect of aid on two

${ }^{11}$ The data groups all non-state actors,including NGOs and political parties, in the same category. Table A5 lists the distinct purposes for democracy and governance aid as coded by AidData (2010).

${ }^{12}$ Aid is: $\ln \left(\left(A_{t-1}+A_{t-2}+A_{t-3}\right) / 3\right)$ where $A$ is constant dollar aid commitments per capita. 
additional measures of consolidation: electoral misconduct and opposition vote-share. For the analysis of transitions to and the persistence of multiparty regimes, we adopt a survival approach that accounts for time dependence in the data and include a cubic polynomial of regime duration (Carter and Signorino, 2010). ${ }^{13}$ The control variables are: GDP per capita (log), population (log), and an indicator variable for civil war in the past two years. ${ }^{14}$ While GDP per capita and population are standard controls in models of aid and political outcomes, civil war in recipient countries can cause donors to reduce aid, particularly democracy assistance, and aid often increases substantially after civil wars end. Further, conflict may directly cause political leaders to lose power because many multiparty failure events occur when rebels oust the incumbent.

To address the possibility that donors give more aid to recipient countries they expect to be more democratic, we first examine "placebo" tests to examine whether there is evidence of a reverse causal pathway, from political change to aid disbursement. The bottom left panel of Figure $1 \mathrm{~b}$ shows that on average OECD donors reward multiparty transitions with more democracy aid but not with more economic aid. This suggests that a naive estimate of the influence of democracy aid on transitions may be biased upwards but this would not necessarily be the case for economic aid. The bottom right panel shows that donors both cut economic assistance and increase democracy aid after a multiparty failure event. These tests suggest the possibility that, even though we use a 3-year lagged moving average for aid, naive estimates may be upwardly biased estimates from reverse causation, particularly for democracy aid.

Addressing endogeneity through exogenous and model-based instruments Our identification strategy is three-fold. First, we employ instruments that exploit information from donor

${ }^{13}$ The duration variables are correlated with the number of prior elections; thus we account for the possibility that repeated holding of elections promotes democratic norms (Lindberg, 2006).

${ }^{14}$ Economic and population data are from the Penn World Tables (version 7.0) and data for civil war is from Gleditsch 2002. In the Appendix, we examine the robustness of these results with additional control variables, such as economic growth, participation in an IMF adjustment program, oil rents, and ethnic fractionalization. 
countries to capture the exogenous flows of aid to recipient countries. Second, we probe the exclusion restriction by (a) testing for alternative channels through which aid may affect democratic change in aid-receiving and (b) relaxing the exogeneity assumption to assess how doing so influences the estimates of interest. Third, we employ "internal" model-based instruments to identify the endogenous regressor through first-stage heteroskedasticity following Lewbel (2012).

We construct the exogenous instrument by leveraging information on two donor country characteristics - domestic inflation and the share of women in parliament - which correlate with aid flows but are unlikely to directly influence political outcomes in recipient countries. For example, inflation is associated with higher government spending, which also influences aid spending; and women in parliament is likely to be correlated with aid because as women increase their representation, aid policy often becomes more oriented toward social equality. Recent studies find that female legislators are more likely to support non-military aid as well as social equity in foreign economic policy (Breuning, 2001). These theoretical considerations do not offer clear-cut expectations about how these factors relate to different types of aid, so we select instruments based on how strongly they correlate with different types of aid to identify the most parsimonious model.

While it is impossible to establish statistical exogeneity, we begin by assuming that these factors shape budgetary decisions in donor countries, including the allocation of aid, but do not directly influence political change in recipient countries. Next, we probe the exclusion restriction by testing the association between the excluded instruments and alternative channels of influence; as well as by relaxing this exclusion restriction and treating the instruments as "plausibly exogenous."

Data on donor inflation (Inflation) is from the WDI (2010) and data on female legislators (or women in parliament, WiP) is from the Inter-Parliamentary Union (2012). To construct the excluded instruments, we weight the donor characteristic $Z$ (either Inflation or WiP) by the distance between donor and recipient country. ${ }^{15}$ We then sum across all donors for each recipient in each year. Because donors vary by recipient and donor characteristics change over time, the excluded instruments vary across both time and recipient country.

\footnotetext{
${ }^{15}$ We thank an anonymous reviewer for this suggestion. Appendix C lists details about how the instruments were constructed.
} 
Probing the exclusion restriction An additional concern arises because the factors we identify as statistically related to aid $(Z)$ but causally unrelated to political change in recipient countries may still be correlated with alternative channels that influence the outcome variables. The existence of such variables mean the exclusion restriction may be violated. Our approach to probing the exclusion restriction has two components.

We first show that the excluded instruments are generally uncorrelated with alternative channels through which they might influence the outcome variables. Figure C-3 in the Appendix provides the partial correlation plots for each of the excluded outside instruments, Inflation and WiP, and an array of potential confounders that represent different areas of foreign policy: trade; membership in international government organizations; partnerships with international non-governmental organizations abroad; the stock of recipient-country migrants in donor countries; and security alliances between donor and recipient countries. ${ }^{16}$ If the outside instruments are correlated with these factors, which might be causally related to the outcome variable, then the exclusion assumption is weaker. The partial correlation plots demonstrate that, with the exception of membership in international organizations ( $W i P$ ) and migrant stock (Inflation), there is little empirical connection between the outside instruments and these alternative channels. Appendix B also shows that the reported results are robust to including these variables as controls.

We then relax the exogeneity assumption to assess how doing so influences the estimate of interest. In the spirit of treating the outside instruments as "plausibly exogenous", we show that even if these variables $(Z)$ are weakly related to the outcome, inference from the reported tests is still valid. We employ a conservative approach, which Conley, Hansen and Rossi (2012) call the "unified confidence interval", that allows $Z$ to be correlated (to some extent) with the errors in the outcome equation. As the assumed partial correlation between $Z$ and the outcome varies, the estimate for Economic aid is still valid for the widest plausible range of this correlation. The estimate for Democracy aid is valid for a smaller range of this correlation, implying that the exogeneity assumption about the outside instrument $(W i P)$ must be stronger for valid inference. ${ }^{17}$

\footnotetext{
${ }^{16}$ Appendix $\mathrm{C}$ lists details about the data sources of the alternative channel measures.

${ }^{17}$ Appendix $\mathrm{C}$ includes a detailed description of our "plausibly exogenous" approach. Figure C3
} 
Because it is difficult to find appropriate instruments that satisfy the exclusion restriction, we complement the "outside" instruments with information from "internal" instruments using an approach that exploits the fact that covariance between the "first-stage" errors and the exogenous variables $(X)$ is not necessarily zero but rather heteroskedastic Lewbel $(2012,67) .{ }^{18}$ Consider the following two-equation model:

$$
\begin{aligned}
Y_{1} & =\beta_{1} X+\gamma_{1} A i d+\epsilon_{1} \\
A i d & =\beta_{2} X+\gamma_{2} Z+\epsilon_{2}
\end{aligned}
$$

The main outcome variable of interest $\left(Y_{1}\right)$ is a function of covariates $(X)$ and Aid, which is endogenous (mismeasured). If $Z$ is correlated with aid but unrelated to $Y_{1}$, then $Z$ may be used as an "outside" excluded instrument to generate predicted values of Aid. If, however, the $\operatorname{cov}\left(X, \epsilon_{2}^{2}\right) \neq 0$, the "first stage" residuals can be exploited as an "inside" excluded instrument. Because the heteroskedasticity arises from the "first stage", this does not threaten inference about $Y_{1}$. The construction of an "internal" excluded instrument is the following: (1) calculate the residual from a "first-stage" regression $\left(\epsilon_{i, t}\right) ;(2)$ calculate the in-sample deviation from the mean for each independent variable in the first stage regression $\left(X_{i, t},-\mu_{X}\right)$; and finally $(3)$ multiply the two: $I=\epsilon_{i, t} \times\left(X_{i, t},-\mu_{X}\right)$. We choose $Z$ based on maximizing the "first-stage" explanatory power; and employ $I$ for each of the variables in $X$ (GDP pc, Population, and duration polynomials)

What is more, by employing "Lewbel" instruments, which are constructed to be orthogonal to the outcome error process, we can use standard diagnostic tests to assess the extent to which the excluded "outside" instruments $(Z)$ are orthogonal to the outcome errors. For each specification, we report the p-value of the $\mathrm{C}$-statistic, which under the null indicates whether the suspect instruments are valid. Thus p-values larger than conventional cut-points (e.g. 0.10) indicate the exclusion restriction is satisfied. We find no evidence that, conditional on the assumption that the Lewbel reports the relevant coefficient estimates.

${ }^{18}$ See Appendix C for discussion of this method in our application; and Finkel, Pérez-Lián and Seligson (2007) for a similar application in the aid literature. Appendix Table C1 reports BreuschPagan tests for the presence of heteroskedasticity in the first-stage equations. 
instruments are valid, the outside instruments are correlated with the outcome errors.

\section{Results}

Table 1 reports tests for transitions to multiparty rule. The first three columns examine economic aid. Column 1 reports the OLS estimate while column 2 reports the IV estimate; Economic aid is positive and significant in both. The third column reports an IV probit model to ensure that the result does not depend on the linear link function. In the first stage, Inflation is positively correlated with economic aid, as expected. The F-statistic for the excluded instruments exceeds the 5 percent threshold for the Stock \& Yogo (2005) weak ID test, indicating an excluded instrument set that is strongly correlated with economic aid. Further, the C-statistic indicates that Inflation meets the exclusion restriction, conditional on the assumption that the other excluded instruments are valid.

The IV estimate for Economic aid is larger than the OLS estimate. This difference would be consistent with donors providing aid to countries that are less likely to transition to electoral multipartyism, especially in the late 1980s and early 1990s. For example, in June 1989 U.S. President Bush welcomed Zairian President Mobutu as the first visiting African head of State during his presidency, declaring him a close friend and staunch ally who deserved substantial financial support. By 1993, however, after the Clinton administration cut aid to Zaire, Mobutu declared "I am the latest victim of the cold war, no longer needed by the U.S." (Zagorin, 1993). One way to gain leverage on this conjecture is to exclude the first years of the sample to see if the coefficients converge. Indeed, when we exclude the first four years of the sample (with lagged aid measured from 1986-1991) the respective linear coefficients are 0.075 (OLS) and 0.089 (IV), while the probit coefficients are 0.302 (probit) and 0.310 (IV-probit).

The next three columns report corresponding models for democracy aid. Consistent with the placebo tests in the bottom left panel of Figure 1b, the estimate for Democracy aid is slightly smaller but not statistically significant in the two-stage models. The "Lewbel" instruments in this sample for this measure of aid do not contribute much explanatory power in the first stage (as shown by the relatively small F-statistic for $I$ only) because the errors from the first stage equation 
do not have substantial heteroegeneity. ${ }^{19}$

To test the robustness of the Economic aid finding, we estimate specifications that: (1) include additional controls variables; (2) employ only the "Lewbel" instruments and not Inflation; (3) add two-way (time period and country) fixed effects; and (4) drop small island countries. Second, we estimated the IV probit model when excluding one country at a time (Figure B1). Third, we estimated "naive" fixed effects linear probability models with: (a) a quadratic time trend; and (b) country-specific time trends (B3). The result for Economic aid remains in each of these tests.

Table 2 presents results for multiparty failure, with a similar set of specifications. Because the dependent variable is multiparty failure, a negative coefficient estimate reflects a factor that increases the likelihood of multiparty survival. The estimates for Economic aid suggest a null finding; if anything the two-stage estimate indicates that this type of aid increases the chances of multiparty failure (but it is not statistically different from zero). And while the F-statistic is below the standard cut-points for weak ID tests, this results from the fact that the Lewbel instruments add little explanatory power in the first stage (the F-statistic for $I$ only is quite low). We obtain a similar negative but insignificant estimate without the "Lewbel" instruments.

Turning to the estimates for Democracy aid, we find a consistent negative relationship with multiparty failure. Both with and without the "Lewbel" instruments, the F-statistic is greater than the thresholds indicating a weak instrument. Further, the C-statistic indicates that WiP meets the exclusion restriction, conditional on the "Lewbel" instruments being valid.

To test the robustness of the Democracy aid finding, we estimate specifications that: (1) include more control variables and no controls beyond duration; (2) employ only the "Lewbel" instruments based on duration time; (3) add two-way (time period and country) fixed effects; and (4) drop small island countries. Second, we estimate the IV probit model when excluding one country at a time (Figure B1). Third, we estimate "naive" fixed effects linear models with: a quadratic time

\footnotetext{
${ }^{19}$ This causes the F-statistic for all excluded instruments $(Z$ and $I)$ to decrease. In Appendix $\mathrm{C}$, we report tests of heterogeneity in the first-stage to explore the extent to which the "Lewbel" instruments boost efficiency. In Table C2, we report a similar null result for Democracy aid when using only WiP as an excluded instrument, with a large F-statistic.
} 
trend; and country-specific time trends (B3). The result for Democracy aid remains.

The top panel of Figure 3 depicts a substantive interpretation of the findings for multipartyism. The left panel uses the estimates from Table 1, model 3 to simulate the risk of multiparty transition across values of economic aid. In this sample the outcome of interest occurs in 13 percent of observation years. Increasing economic aid from the 25 th percentile to the 75 th percentile is associated with an increase in the simulated transition risk from roughly 6 percent to 11 percent. The right panel shows the simulations for democracy aid and multiparty failure from column 6 , Table 2. In this sample, multiparty failure occurs in just over 2 percent of observations. Increasing democracy aid from the 25 th pcentile to the 75 th percentile reduces the simulated risk of breakdown by over two-thirds, from 3.5 percent to 0.8 percent. $^{20}$

\section{Foreign aid and African elections}

In this section we examine how foreign aid influences elections in sub-Saharan Africa. Thus far, we have shown that economic aid increases the chances of transition to multiparty politics but has little influence on the survival of multiparty politics. Democracy assistance, on the other hand, has little influence on the introduction of multiparty politics but helps multipartyism persist. However, this analysis, does not capture democratic consolidation outcomes that might threaten the incumbent. One outcome that represents a potential threat to the incumbent's ability to retain power is electoral misconduct. A second outcome, which more directly threatens incumbents in multiparty regimes, is stronger electoral support of opposition parties.

Electoral misconduct We look first at observed incumbent behavior during multiparty election years, using an indicator of electoral malfeasance by the incumbent constructed from variables in the NELDA data set: opposition harassment, preventing opposition parties from participating, and violence involving civilian deaths (Hyde and Marinov, 2012). These concepts capture aspects of

${ }^{20}$ While the simulations indicate that the aid estimates reported in Tables 1 and 2 are substantively important, the simulation estimates should not be interpreted literally because the absolute size of the estimates reflects the observed incidence of the dependent variable in each of the samples. 
electoral misconduct using information from election observer reports. The dependent variable is coded 1 if any of these types of misconduct occur during an election year; and 0 otherwise. Just under one-half of multiparty election years are coded as incumbent misconduct.

The explanatory variables include foreign aid, GDP per capita (log), population (log), IMF program participation, whether election monitors were present, and whether the election was the first multiparty election. ${ }^{21}$ IMF program participation and the presence of election monitors may shape aid allocation; and as Hyde and O'Mahony (2010) show, these factors also influence whether the incumbent government attempts to win elections by focusing more on pre-electoral fiscal manipulation or direct manipulation such as vote stealing, intimidation, and harassing the opposition. Again we use a two-stage linear probability model, and check results with an IV-probit.

The first three columns of Table 3 examine economic aid. While the estimates for Economic aid are negative, they are not statistically different from zero; and the IV estimate is lower in absolute size than the OLS estimate. The F-statistic indicates an instrument set that is strongly correlated with economic aid; and the C-statistic suggests that Inflation is a valid instrument, conditional on the assumption that the "Lewbel" instruments are valid.

The estimates for Democracy aid show no result in the OLS model, but yield negative and significant estimates in the IV models. This suggests that the naive estimates may reflect donors giving more governance aid prior to multiparty contests in low state-capacity countries where electoral misconduct is likely, precisely because it is more difficult for the government to conduct an election in these countries. ${ }^{22}$ This scenario would be consistent, for example, with donors

${ }^{21}$ The NELDA data include measures of whether the election was the first multiparty contest and whether monitors are present. In robustness tests we show the results hold when adding further control variables: economic growth, civil conflict, ethnic fractionalization, trade, IGOs, NGOs, membership in IOs, migrant stock, and ally. Further controls from NELDA are indicators of whether the incumbent expected to win the election and whether there was an opposition boycott.

${ }^{22}$ Using the "Lewbel" instruments in this sample for democracy aid lowers the overall F-stat $(Z+I)$ to about 10 because the F-stat for these 'internal' instrument $(I)$ is small: 1.8. Reestimating the models with only $Z$ and not $I$ as an excluded instrument increases the F-stat such 
financing roughly 90 percent of the costs associated with the 2006 election in the DRC, which was marred by violence (Kadima, Leonard and Schmidt, 2009, 24). The bottom panel of Figure 3 plots the simulated effect of democracy aid on the probability of observing electoral misconduct, from estimates in last column of Table 3. An increase in democracy aid from the 25th percentile to the 75th percentile lowers the simulated probability of misconduct from over 55 percent to 38 percent.

These findings are consistent with the results for multiparty breakdown: democracy assistance is associated with a more democratic outcome, in this case a lower likelihood of electoral misconduct. Economic aid, on the other hand, appears to have little consistent influence on electoral misconduct. The result for democracy aid is robust to additional control variables; and when dropping small island countries or civil war years from the sample.

Electoral support for the opposition Does democracy aid increase the strength of opposition parties? Our measure of opposition electoral support is the percentage vote for the largest opposition party (or candidate) as a share of the two-party vote: $\frac{O}{O+I}$, where $O$ is the vote share for the largest opposition party and $I$ is the vote share for the incumbent. This operationalization circumvents issues related to the fragmentation of party systems by focusing on a continuous measure of how close the largest opposition party is to defeating the incumbent at the polls. We concentrate on first round executive elections after a transition to multiparty politics because these contests pit the incumbent party against opposition candidates and capture support for the largest opposition party. We fit a linear model with a log-transformed dependent variable to account for the proportional nature of the vote share data.

Table 4 reports the results. Given the small number of observations, we use a minimum of control variables: GDP per capita, population, economic growth, and IMF program participation. The first three columns examine economic aid, the latter three democracy aid. For each, we report a naive model, an IV model, and one with the sample restricted to elections in which the incumbent wins less than $90 \%$ of the vote, as was the case in Equatorial Guinea in 1996 and 2002. ${ }^{23}$

that it easily passes weak instrument tests. Further, the $\mathrm{C}$-statistic indicates that WiP is a valid instrument, conditional on the others being valid.

${ }^{23}$ Of the 84 elections in the sample, the largest opposition party takes at least $10 \%$ of the vote 
The estimate for Economic aid is positive in the naive model but becomes negative in the IV model, though neither estimate is different from zero. We find a consistent negative estimate for economic aid in various alternative IV specifications reported in the Appendix, but none of the estimates are statistically different from zero. Despite the lack of statstical significane, this suggests that once we account for endogeneity, economic aid might hurt electoral competitiveness. For democracy aid, the naive and the IV estimate on the full sample yield positive estimates but these findings hinge entirely on including elections where the incumbent wins handily, as illustrated by the null finding in column 6. Democracy aid has little influence on opposition support in elections that are minimally competitive. The F- and C-statistics indicate valid instruments.

\section{An aid curse?}

Several studies posit that aid inhibits democracy by reducing political accountability for recipient governments (Remmer, 2004; Moss and van de Walle, 2008). Non-tax revenue such as aid relieves the state of taxing citizens, which may reduce citizens' incentive to demand accountability (Djankov and Reynal-Querol, 2008, 172). Recent studies, however, find that aid does not hurt tax effort (Carter, 2013; Morrissey, 2014) and has few deleterious effects on democracy post-1989 (Bermeo, 2011, 2013). While our findings suggest that economic aid helped purchase multiparty transitions in Africa - a finding consistent with aid curse dissenters (Dunning, 2004; Wright, 2009; Bermeo, 2011) - this form of aid is nonetheless associated with an increased risk of multiparty failure and lower opposition vote shares (though neither of these results are statistically significant). That said, the aid curse literature focuses on economic, not democracy, assistance. We find that though democracy assistance is associated with more stable multiparty systems and fair elections, there is little evidence that it helps the electoral opposition. Thus, once we examine different types of foreign aid and distinct aspects of democratic politics, the findings do not fit neatly with "aid curse" or "aid blessing" labels. Rather, the picture is more complicated because we account for donor strategies and the possibility that some forms of political change - such as multiparty transitions and fair

in 70 cases, but fails to reach this threshold in 14 cases. These 14 cases receive roughly half the democracy aid (on average) than the other 70 cases: $\$ 2.3$ per capita vs. $\$ 4.0$. 
elections - are not necessarily threatening to incumbents.

\section{Conclusion}

The findings suggest several insights into the relationship between foreign aid, democratic transition and consolidation in Africa. While economic aid is a catalyst for transitions to multiparty party regimes, democracy aid stabilizes multiparty regimes and decreases the incidence of electoral misconduct, which we interpret as increasing horizontal accountability. Importantly, neither of these outcomes may necessarily threaten incumbent governments in institutionalized multiparty regimes. However, we find little evidence that either economic or democracy aid increases the competitiveness of the opposition, which is a necessary condition for incumbent turnover. This sugggests that the primary channel through which democracy promotion occurs is government-led political reform. In short, we find evidence consistent with both the leverage mechanism linking economic aid to multiparty transitions as well as the investment mechanism linking democracy aid to consolidation outcomes - but only those that do not necessarily threaten incumbents.

Despite the rhetoric about strengthening civil society, we show that donors largely pursue democracy promotion through governance aid, with predictable effects on maintaining a stable multiparty electoral system. If the goal of democracy promotion is to increase opposition strength and, more broadly, consolidate democracy through channels that improve vertical accountability, we would expect donors to directly invest in opposition parties and civil society groups. This in turn, should promote vertical accountability by increasing the electoral strength of opposition parties. If, on the other hand, democracy aid largely targets governance programs and is implemented by incumbent parties, it is less likely that external democracy promotion yields reform outcomes that put incumbents at risk of losing power. Instead democracy aid may perpetuate a multiparty system in which incumbents retain power. Thus our finding for multiparty transitions and failure dovetails with Crawford Young's $(1999,35)$ claim that "semi-democracy is probably sufficient to deflect international system pressures for more complete political opening, particularly if macroeconomic management earns external approbation."

While our results are robust to excluding post-civil conflict periods from the tests of multiparty 
stability, more can be done to account conflict's consequences on processes of democratic change. As Flores and Nooruddin (2009) and Flores and Nooruddin (2012) show, aid flows often spike during post-conflict periods. Future research should further investigate the political consequences of post-conflict-induced aid.

Finally, even though we find little evidence that democracy assistance strengthens opposition parties in elections, we cannot rule out the possibility that democracy promotion efforts that improve other consolidation outcomes - such as maintaining a stable multiparty regime and improving the conduct of elections - will bolster opposition parties at the polls in the future. A more level playing field may induce further domestic investment in opposition groups down the road.

\section{References}

Bermeo, Sarah. 2011. "Foreign Aid and Regime Change: A Role for Donor Intent." World Development 39(11):2021 - 2031.

Bermeo, Sarah Blodgett. 2013. "Aid is Not Oil: Donor Preferences, Heterogeneous Aid, and the Aid-Democratization Relationship.".

Boulding, Carew. 2010. "NGOs and Political Participation in Weak Democracies: Sub-national Evidence on Protest and Voter Turnout from Bolivia." Journal of Politics 72(2):456-68.

Brautigam, Deborah and Stephen Knack. 2004. "Foreign Aid, Institutions, and Governance in Sub-Saharan Africa." Economic Development and Cultural Change 52(2):255-285.

Breuning, Marijke. 2001. "Women's representation and development assistance: a cross-national study." Women 83 Politics 23(3):35-55.

Brown, Stephen. 2011. "Well, What Can You Expect? Donor Officials' Apologetics for Hybrid Regimes in Africa." Democratization 18(2):512-534.

Bueno de Mesquita, Bruce and Alastair Smith. 2009. "A Political Economy of Foreign Aid." International Organization 63:309-340. 
Burnell, Peter. 1997. Foreign Aid in a Changing World. Buckingham: Open University Press.

Carter, David and Curt Signorino. 2010. "Back to the Future: Modeling Time Dependence in Binary Data." Political Analysis 18(3):271-292.

Carter, Patrick. 2013. “Does Foreign Aid Displace Domestic Taxation?" Journal of Globalization and Development 4(1):1-47.

Cheeseman, Nic. 2011. "African Elections as Vehicles for Change." Journal of Democracy 21(4):139153.

Cheibub, José Antonio, Jennifer Gandhi and James Raymond Vreeland. 2010. "Democracy and Dictatorship Revisited." Public Choice 143(1-2):67-101.

Cole, N. Scott. 2007. "Hugo Chavez and President Bush's Credibility Gap: The Struggle Against U.S. Democracy Promotion." International Political Science Review 28(4):493-507.

Conley, Timothy G, Christian B Hansen and Peter E Rossi. 2012. "Plausibly exogenous." Review of Economics and Statistics 94(1):260-272.

Crawford, Gordon. 2001. Foreign Aid and Political Reform: A Comparative Analysis of Democracy Assistance and Political Conditionality. New York: Palgrave Macmillan.

Diamond, Larry. 1992. "Promoting democracy." Foreign Policy (87):25-46.

Dietrich, Simone. 2011. "The Politics of Public Health Aid: Why Corrupt Governments Implement Health Aid Effectively." World Development 39(1):55-63.

Dietrich, Simone. 2013. "Bypass or Engage? Explaining Donor Delivery Tactics in Foreign Aid Allocation." International Studies Quarterly 57(4):698-712.

Dietrich, Simone. 2014. "Donor Political Economies and the Pursuit of Aid Effectiveness.".

Djankov, S., J.G. Montalvo and M. Reynal-Querol. 2008. "The Curse of Aid." Journal of Economic Growth 13(3):169-194. 
Dunning, Thad. 2004. "Conditioning the Effects of Aid: Cold War Politics, Donor Credibility, and Democracy in Africa." International Organization 58(2):409-423.

Finkel, Steven E., Anìbal Pérez-Lián and Mitchell A. Seligson. 2007. "The Effects of U.S. Foreign Assistance on Democracy Building, 1990-2003." World Politics 59:404-439.

Flores, Thomas E. and Irfan Nooruddin. 2009. "Financing the Peace: Evaluating World Bank Post-Conflict Assistance Programs." Review of International Organizations 4(1):1-27.

Flores, Thomas E. and Irfan Nooruddin. 2012. "The Effect of Elections on Postconflict Peace and Reconstruction." Journal of Politics 74(2):558-570.

Gazibo, Mamoudou. 2013. Beyond Electoral Democracy: Foreign Aid and the Challenge of Deepening Democracy in Benin. In Democratic Trajectories in Africa: Unravelling the Impact of Foreign Aid, ed. Danielle Resnick and Nicolas van de Walle. Oxford University Press.

Goldsmith, Arthur A. 2001. "Foreign Aid and Statehood in Africa." International Organization $55(1): 123-148$.

Gyimah-Boadi, E. and Theo Yakah. 2013. Ghana: The Limits of External Democracy Assistance. In Democratic Trajectories in Africa: Unravelling the Impact of Foreign Aid, ed. Danielle Resnick and Nicolas van de Walle. Oxford University Press.

Handley, Antoinette. 2008. "The World Bank Made Me Do It? International Factors and Ghana's Transition to Democracy." CDDRL Working Papers n.82.

Harding, Robin and David Stasavage. 2014. "What Democracy Does (and Doesn't do) for Basic Services: School Fees, School Inputs, and African Elections." Journal of Politics Forthcoming.

Herszenhorn, David M. and Ellen Barry. 2012. "Russia Demands U.S. End Support of Democracy Groups.” New York Times . September 18, 2012. [accessed 4 April 2013].

Huber, Evelyne, Thomas Mustillo and John D. Stevens. 2008. "Politics and Social Spending in Latin America." Journal of Politics 70(2):420-36. 
Hyde, Susan D and Angela O’Mahony. 2010. "International scrutiny and pre-electoral fiscal manipulation in developing countries." The Journal of Politics 72(03):690-704.

Hyde, Susan and Nikolay Marinov. 2012. "Which Elections Can Be Lost?" Political Analysis 20(2):191-210.

Kadima, Denis, David K Leonard and Anna Schmidt. 2009. "Elections and democratisation in the Democratic Republic of Congo." Journal of African Elections: Elections and conflict in Africa $8(1): 14-48$.

Lewbel, Arthur. 2012. "Using heteroscedasticity to identify and estimate mismeasured and endogenous regressor models." Journal of Business \& Economic Statistics 30(1).

Lindberg, Staffan I. 2006. Democracy and Elections in Africa. Baltimore: The Johns Hopkins University Press.

Morrissey, Oliver. 2014. "Aid and Government Fiscal Behavior: Assessing Recent Evidence." World Development .

Moss, Todd, Gunilla Petterson and Nicolas van de Walle. 2008. An Aid-Institutions Paradox? A Review essay on Aid Dependency and State Building in Sub-Saharan Africa. In Reinventing Foreign Aid, ed. William Easterly. Cambridge University Press.

Nielsen, Richard A, Michael G Findley, Zachary S Davis, Tara Candland and Daniel L Nielson. 2011. "Foreign aid shocks as a cause of violent armed conflict." American Journal of Political Science 55(2):219-232.

Posner, Dan and Daniel Young. 2007. "The institutionalization of political power in Africa." Journal of Democracy 18(3):126-140.

Rakner, Lise. 2013. Foreign Aid and Democratic Consolidation in Zambia. In Democratic Trajectories in Africa: Unravelling the Impact of Foreign Aid, ed. Danielle Resnick and Nicolas van de Walle. Oxford University Press. 
Remmer, Karen. 2004. "Does Foreign Aid Promote the Expansion of Government?" American Journal of Political Science 48:77-92.

Resnick, Danielle. 2013. Foreign Aid in Africa: Tracing Channels of Influence on Democratic Transitions and Consolidation. In Democratic Trajectories in Africa: Unravelling the Impact of Foreign Aid, ed. Danielle Resnick and Nicolas van de Walle. Oxford University Press.

Savun, Burcu and Daniel Tirone. 2012. "Exogenous Shocks, Foreign Aid, and Civil War." International Organization 66(3):363-393.

Scott, James M. and Carie A. Steele. 2011. "Sponsoring Democracy: The United States and Democracy Aid to the Developing World, 19882001." International Studies Quarterly 55(1):4769.

Sen, Amartya. 1999. Development as freedom. Oxford University Press.

Stasavage, David. 2005. "Democracy and Education Spending in Africa." American Journal of Political Science 49(2):348-58.

Tripp, Aili. 2012. "Donor Assistance and Political Reform in Tanzania." UN-Wider Working Paper 37.

Van de Walle, Nicolas. 2013. Foreign Aid in Dangerous Places: The Donors and Mali's Democracy. In Democratic Trajectories in Africa: Unravelling the Impact of Foreign Aid, ed. Danielle Resnick and Nicolas van de Walle. Oxford University Press.

Wright, Joseph. 2009. "How Foreign Aid Can Foster Democratization in Authoritarian Regimes." American Journal of Political Science 53(3):552-571.

Zagorin, Adam. 1993. "Leaving Fire in His Wake: Mobutu Sese Seko." TIME Magazine . February 22, 1993. [accessed 2 March 2014]. 
Simone Dietrich is an Assistant Professor in Political Science at the University of MissouriColumbia. She specializes in international political economy and development; and studies foreign aid allocation mechanisms. Her research has been published in International Studies Quarterly and World Development.

Joseph Wright is an Assistant Professor in Political Science at the Pennsylvania State University. He studies comparative political economy and autocratic politics, with a particular interest in how international factors - such as foreign aid, economic sanctions, human rights prosecutions and migration - influence domestic politics in autocratic contexts. 
Table 1: Foreign aid and transitions to multipartyism

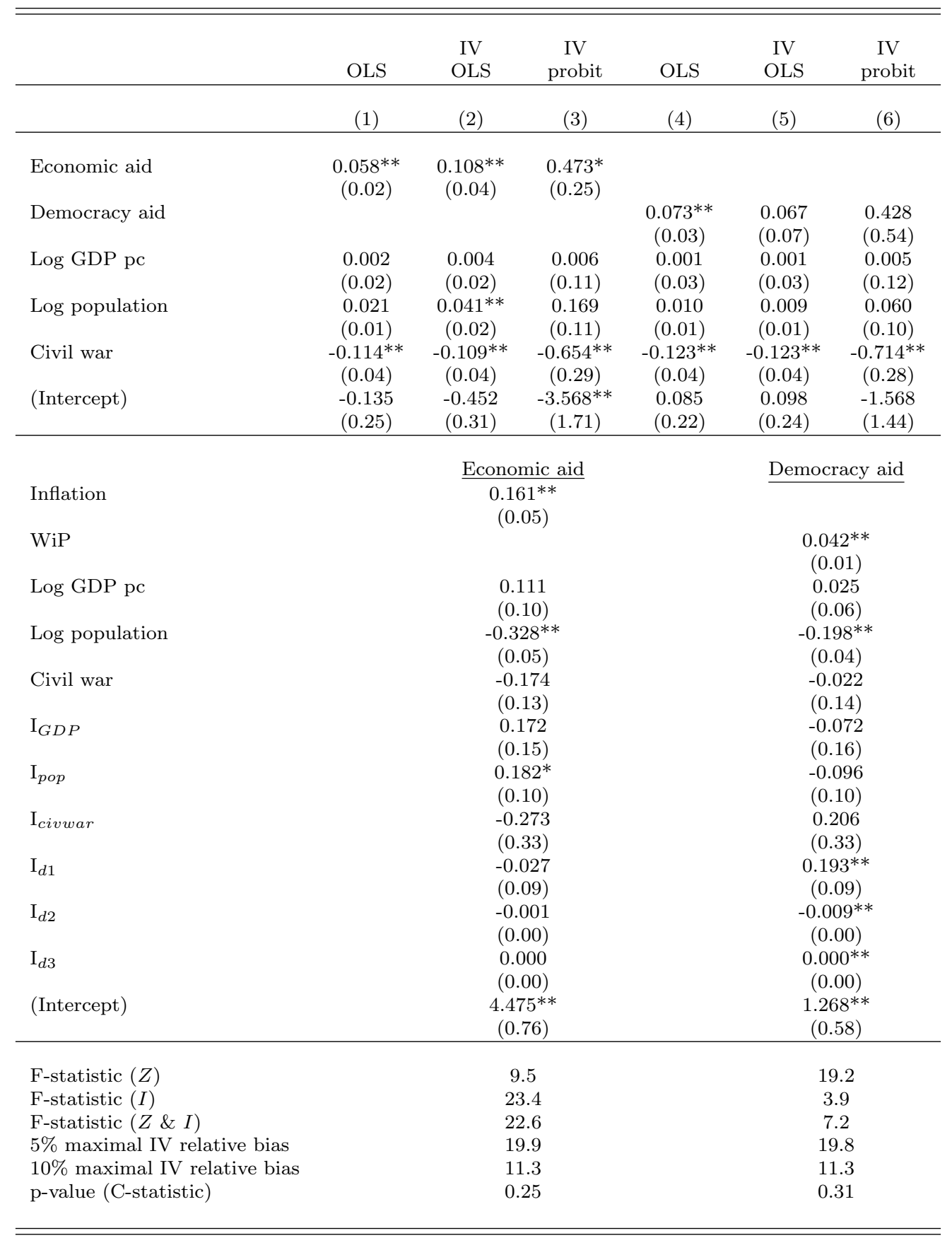

${ }^{*} \mathrm{p}<0.10 ;{ }^{* *} \mathrm{p}<0.05$. Duration polynomials (3) not reported. F-statistic is the Kleibergen-Paap rk Wald F statistic. $\mathrm{N} \times \mathrm{T}=370$ observations in 44 countries from 1989-2008. First-stage F-statstic based on 43 degrees of freedom. 
Table 2: Foreign aid and multiparty failure

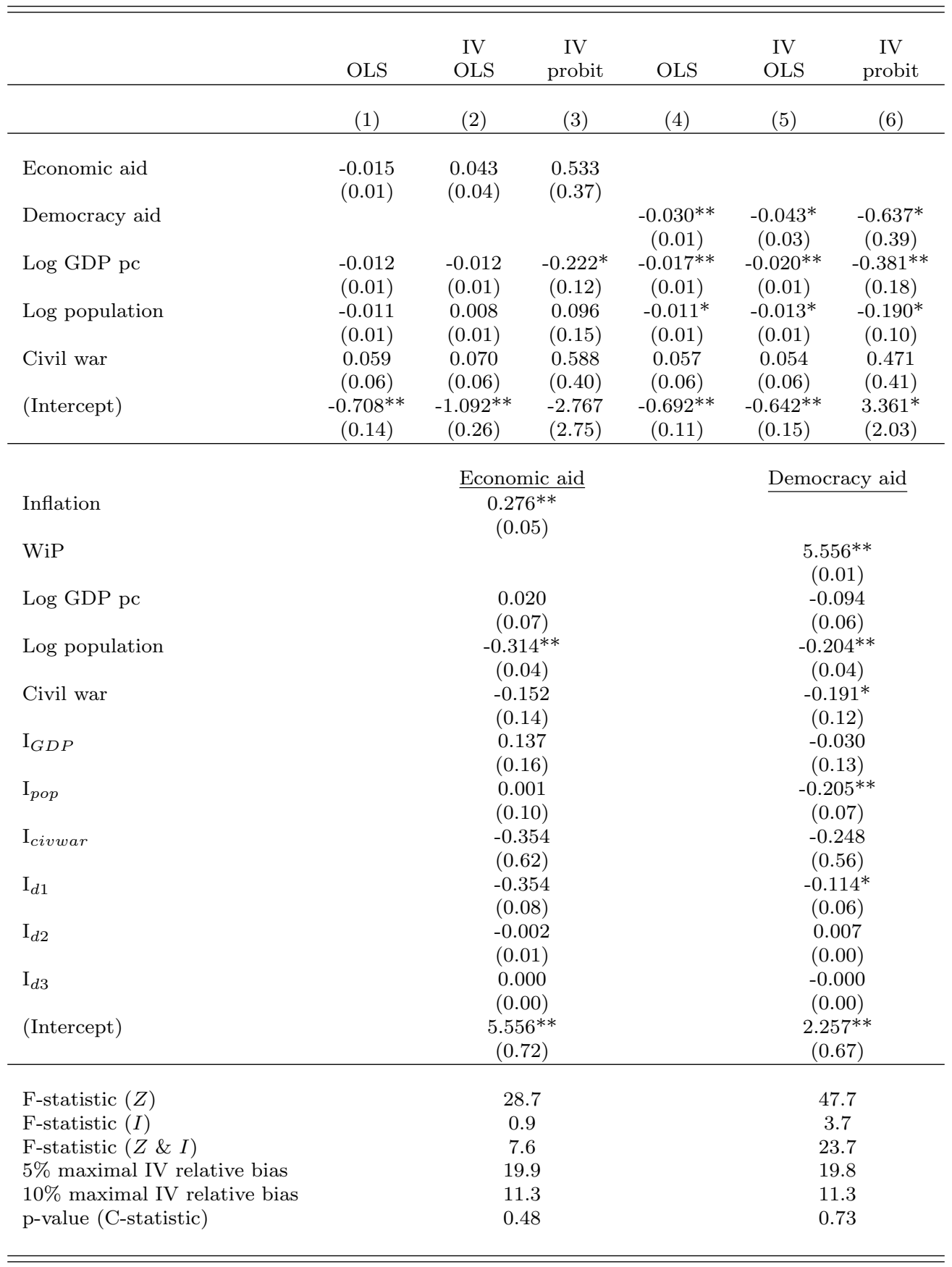

${ }^{*} \mathrm{p}<0.10 ;{ }^{* *} \mathrm{p}<0.05$. Duration polynomials (3) not reported. F-statistic is the Kleibergen-Paap Wald F statistic. $\mathrm{N} \times \mathrm{T}=583$ observations in 44 countries from 1989-2008. 
Table 3: Foreign aid and electoral misconduct

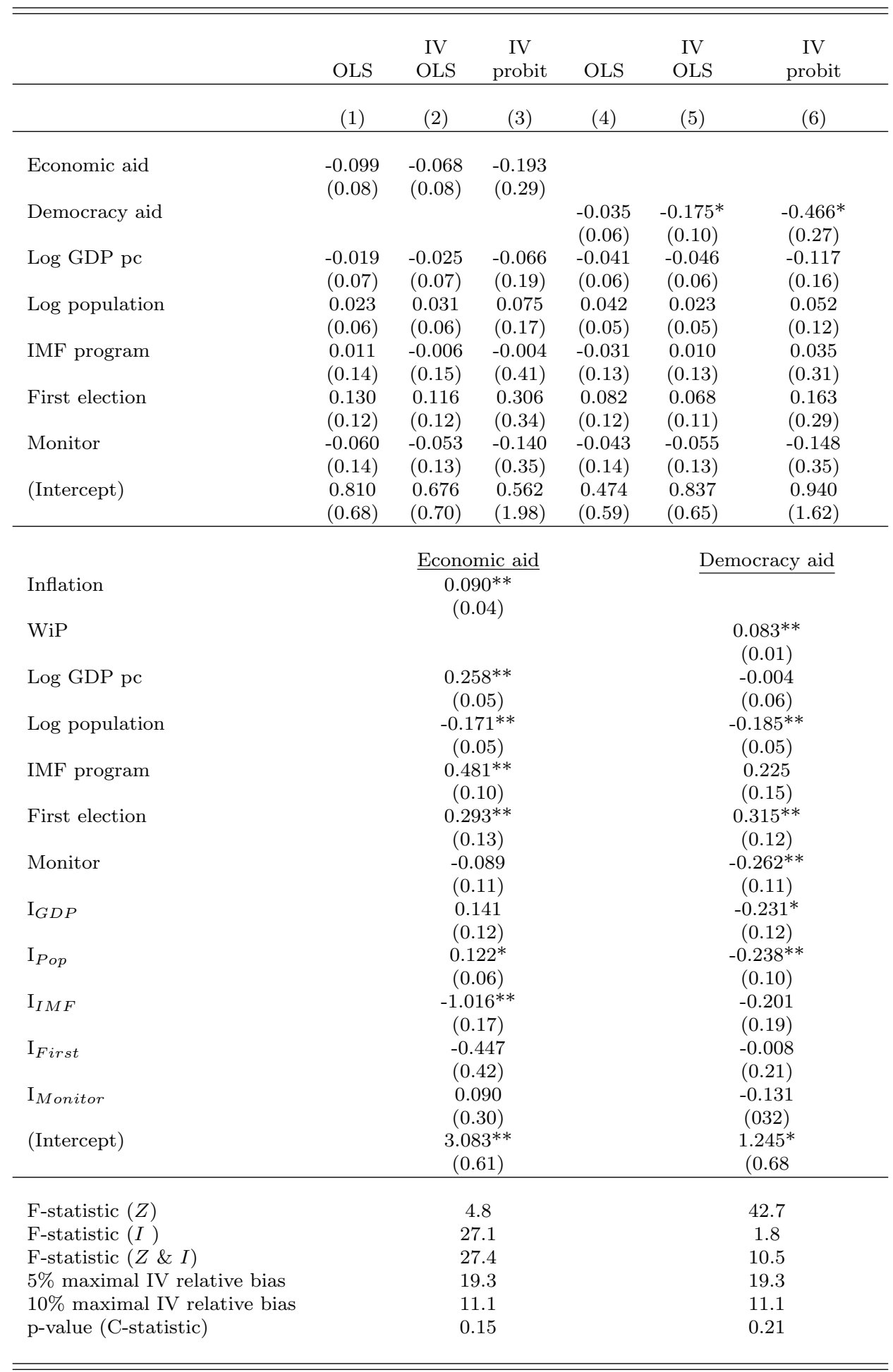

${ }^{*} \mathrm{p}<0.10 ;{ }^{* *} \mathrm{p}<0.05$. F-statistic is the Kleibergen-Paap Wald $\mathrm{F}$ statistic. 170 election years in 40 countries from $1989-2008$. 
Table 4: Foreign aid and opposition vote share

\begin{tabular}{|c|c|c|c|c|c|c|}
\hline & OLS & IV & IV & OLS & IV & IV \\
\hline & $(1)$ & $(2)$ & $(3)$ & $(4)$ & $(5)$ & $(6)$ \\
\hline Economic aid & $\begin{array}{l}0.262 \\
(0.32)\end{array}$ & $\begin{array}{l}-0.361 \\
(0.29)\end{array}$ & $\begin{array}{c}-0.273 \\
(0.21)\end{array}$ & & & \\
\hline Democracy aid & & & & $\begin{array}{c}0.578^{* *} \\
(0.26)\end{array}$ & $\begin{array}{c}1.002^{* *} \\
(0.44)\end{array}$ & $\begin{array}{l}0.146 \\
(0.25)\end{array}$ \\
\hline Log GDP pc & $\begin{array}{c}-0.193 \\
(0.13)\end{array}$ & $\begin{array}{l}-0.113 \\
(0.14)\end{array}$ & $\begin{array}{c}-0.210^{* *} \\
(0.09)\end{array}$ & $\begin{array}{c}-0.088 \\
(0.15)\end{array}$ & $\begin{array}{l}-0.036 \\
(0.16)\end{array}$ & $\begin{array}{c}-0.213^{* *} \\
(0.10)\end{array}$ \\
\hline Log population & $\begin{array}{l}0.011 \\
(0.19)\end{array}$ & $\begin{array}{l}-0.185 \\
(0.18)\end{array}$ & $\begin{array}{c}-0.227^{* *} \\
(0.08)\end{array}$ & $\begin{array}{l}0.018 \\
(0.13)\end{array}$ & $\begin{array}{l}0.083 \\
(0.15)\end{array}$ & $\begin{array}{l}-0.108 \\
(0.08)\end{array}$ \\
\hline Growth & $\begin{array}{l}-0.021 \\
(0.02)\end{array}$ & $\begin{array}{l}-0.027 \\
(0.02)\end{array}$ & $\begin{array}{c}-0.004 \\
(0.01)\end{array}$ & $\begin{array}{c}-0.032 \\
(0.02)\end{array}$ & $\begin{array}{c}-0.038^{*} \\
(0.02)\end{array}$ & $\begin{array}{l}-0.007 \\
(0.02)\end{array}$ \\
\hline IMF program & $\begin{array}{r}-0.096 \\
(0.33)\end{array}$ & $\begin{array}{l}0.136 \\
(0.31)\end{array}$ & $\begin{array}{l}0.250 \\
(0.22)\end{array}$ & $\begin{array}{l}-0.197 \\
(0.32)\end{array}$ & $\begin{array}{c}-0.343 \\
(0.37)\end{array}$ & $\begin{array}{l}0.080 \\
(0.25)\end{array}$ \\
\hline (Intercept) & $\begin{array}{l}-0.587 \\
(3.06) \\
\end{array}$ & $\begin{array}{l}2.897 \\
(2.98) \\
\end{array}$ & $\begin{array}{c}3.905^{* *} \\
(1.35) \\
\end{array}$ & $\begin{array}{l}-0.994 \\
(2.14) \\
\end{array}$ & $\begin{array}{l}-2.367 \\
(2.45) \\
\end{array}$ & $\begin{array}{l}1.720 \\
(1.49) \\
\end{array}$ \\
\hline & \multicolumn{4}{|c|}{ Economic aid } & \multicolumn{2}{|c|}{ Democracy aid } \\
\hline Inflation & & $\begin{array}{c}0.178^{* *} \\
(0.05)\end{array}$ & $\begin{array}{c}0.164 * * \\
(0.05)\end{array}$ & & & \\
\hline WiP & & & & & $\begin{array}{c}0.073^{* *} \\
(0.02)\end{array}$ & $\begin{array}{c}0.081^{* *} \\
(0.03)\end{array}$ \\
\hline Log GDP pc & & $\begin{array}{c}0.204^{* *} \\
(0.07)\end{array}$ & $\begin{array}{c}0.200^{* *} \\
(0.06)\end{array}$ & & $\begin{array}{c}0.009 \\
(0.09)\end{array}$ & $\begin{array}{r}-0.027 \\
(0.10)\end{array}$ \\
\hline Log population & & $\begin{array}{c}-0.289^{* *} \\
(0.05)\end{array}$ & $\begin{array}{c}-0.322^{* *} \\
(0.04)\end{array}$ & & $\begin{array}{c}-0.200^{* *} \\
(0.06)\end{array}$ & $\begin{array}{c}-0.211^{* *} \\
(0.06)\end{array}$ \\
\hline Growth & & $\begin{array}{r}-0.000 \\
(0.01)\end{array}$ & $\begin{array}{l}0.003 \\
(0.01)\end{array}$ & & $\begin{array}{r}-0.006 \\
(0.01)\end{array}$ & $\begin{array}{c}-0.006 \\
(0.01)\end{array}$ \\
\hline IMF program & & $\begin{array}{c}0.428^{* *} \\
(0.13)\end{array}$ & $\begin{array}{c}0.502^{* *} \\
(0.13)\end{array}$ & & $\begin{array}{c}0.507^{* *} \\
(0.16)\end{array}$ & $\begin{array}{c}0.487^{* *} \\
(0.18)\end{array}$ \\
\hline $\mathrm{I}_{G D P}$ & & $\begin{array}{l}-0.057 \\
(0.16)\end{array}$ & $\begin{array}{l}-0.055 \\
(0.14)\end{array}$ & & $\begin{array}{l}-0.116 \\
(0.15)\end{array}$ & $\begin{array}{r}-0.098 \\
(0.17)\end{array}$ \\
\hline $\mathrm{I}_{P o p}$ & & $\begin{array}{l}-0.021 \\
(0.12)\end{array}$ & $\begin{array}{l}0.013 \\
(0.10)\end{array}$ & & $\begin{array}{c}-0.242^{* *} \\
(0.06)\end{array}$ & $\begin{array}{c}-0.240^{* *} \\
(0.09)\end{array}$ \\
\hline $\mathrm{I}_{\text {Growth }}$ & & $\begin{array}{c}0.026^{* *} \\
(0.01)\end{array}$ & $\begin{array}{c}0.040^{* *} \\
(0.01)\end{array}$ & & $\begin{array}{c}-0.042^{* *} \\
(0.02)\end{array}$ & $\begin{array}{c}-0.035^{* *} \\
(0.02)\end{array}$ \\
\hline $\mathrm{I}_{I M F}$ & & $\begin{array}{c}-0.889^{* *} \\
(0.23)\end{array}$ & $\begin{array}{c}-1.076^{* *} \\
(0.20)\end{array}$ & & $\begin{array}{c}-0.094 \\
(0.30)\end{array}$ & $\begin{array}{l}-0.267 \\
(0.35)\end{array}$ \\
\hline (Intercept) & & $\begin{array}{c}4.383^{* *} \\
(0.87) \\
\end{array}$ & $\begin{array}{c}4.707^{* *} \\
(0.77) \\
\end{array}$ & & $\begin{array}{l}1.155 \\
(0.97) \\
\end{array}$ & $\begin{array}{l}1.384 \\
(1.13) \\
\end{array}$ \\
\hline F-statistic $(Z)$ & & 15.3 & 9.4 & & 10.8 & 7.6 \\
\hline F-statistic $(I)$ & & 13.7 & 13.4 & & 12.8 & 7.3 \\
\hline F-statistic $(Z \& I)$ & & 22.5 & 15.5 & & 19.1 & 12.8 \\
\hline $5 \%$ maximal IV relative bias & & 18.4 & 18.4 & & 18.4 & 18.4 \\
\hline $10 \%$ maximal IV relative bias & & 10.8 & 10.8 & & 10.8 & 10.8 \\
\hline p-value (C-statistic) & & 0.19 & 0.51 & & 0.20 & 0.22 \\
\hline
\end{tabular}

${ }^{*} \mathrm{p}<0.10 ;{ }^{* *} \mathrm{p}<0.05$. F-statistic is the Kleibergen-Paap Wald $\mathrm{F}$ statistic. 84 elections in columns 1-2, 4-5; 70 elections in columns 3 and 6. 31 countries from 1989-2008. /Clustered standard errors reported. 
(a) Foreign aid trends over time

Economic Aid

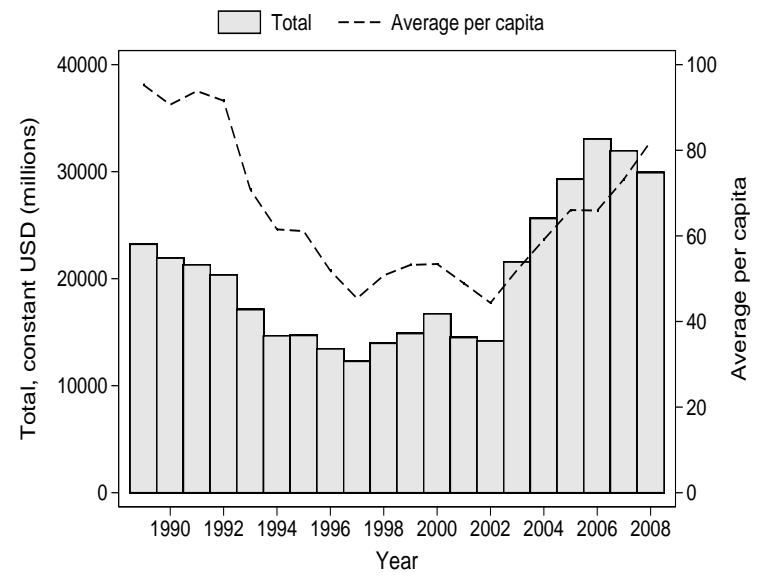

Democracy Aid

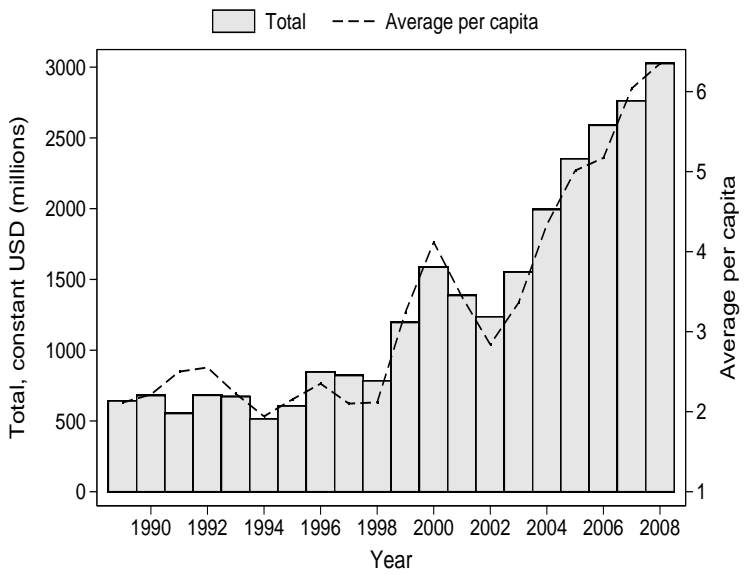

(b) Aid dividend from multiparty transition and collapse

Multiparty transition

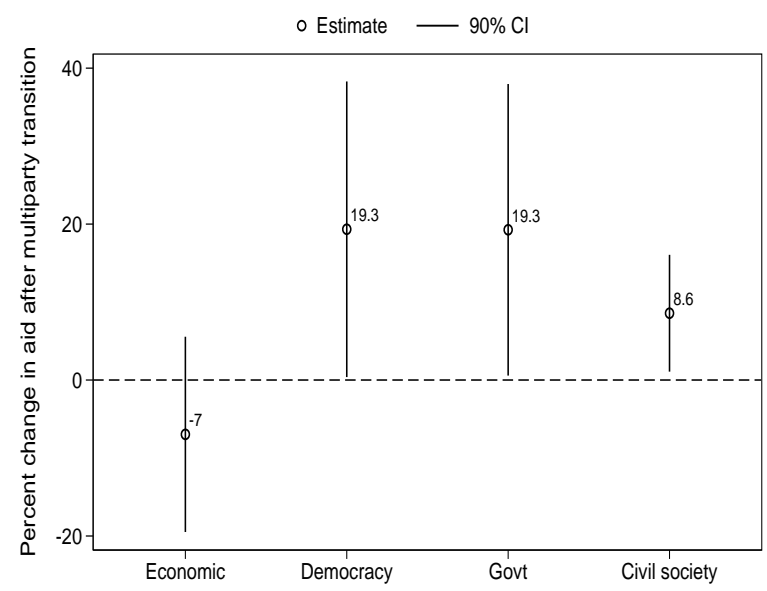

Multiparty failure

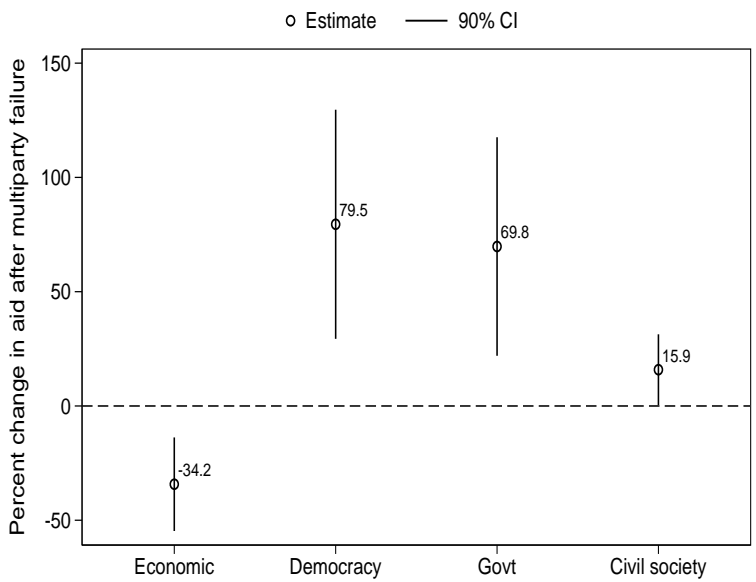

Figure 1: Foreign aid in sub-Saharan Africa. Top panel shows economic aid and democracy and governance aid (DGA). Total is constant USD in millions. Per capita is constant USD averaged across 48 countries. Two year moving average $(t, t-1)$. Bottom panel shows the percent change in aid in the three years after multiparty transition (failure) relative to three years prior to transition (failure). Each panel shows the average change for economic aid, democracy aid, and two categories of democracy aid (civil society and government). Estimates in bottom panel obtained from a country fixed effects regression with controls for civil war, 1989-2008. Sources: AidData.org and authors' calculation. 
Civil society share of DGA

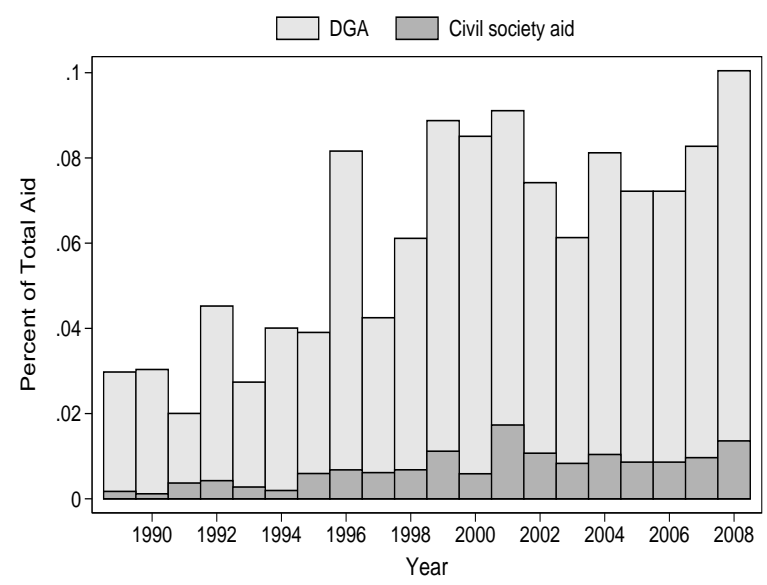

U.S. share of DGA

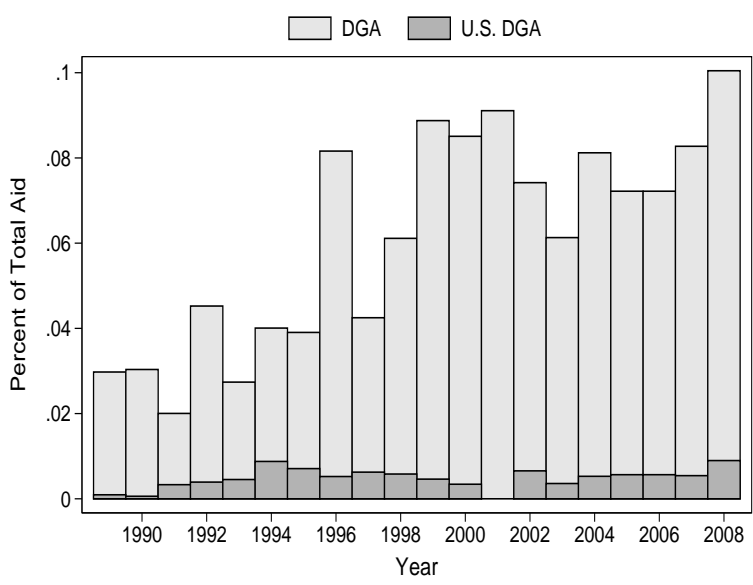

Figure 2: Democracy and Governance Aid (DGA), share of total aid by year. Left panel: large bars depict $\frac{D G A}{\text { AllAid }}$; small, darker bars depict $\frac{\text { CivilSocietyAid }}{\text { TotalDGA }}$. Right panel: large bars depict

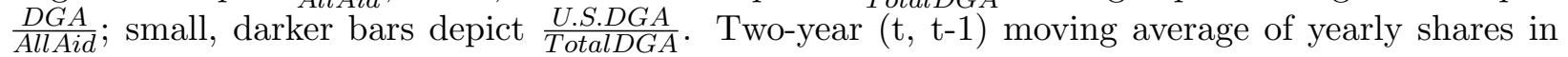
constant dollars. Sources: AidData.org, WDI (2010), and authors' calculation. 
(a) Foreign aid and multipartyism

Economic aid \& transition

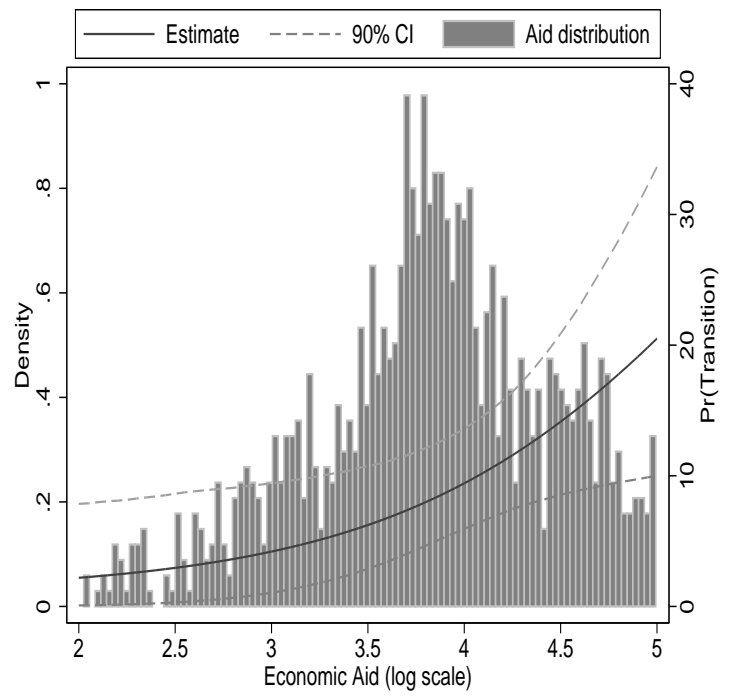

Democracy aid \& failure

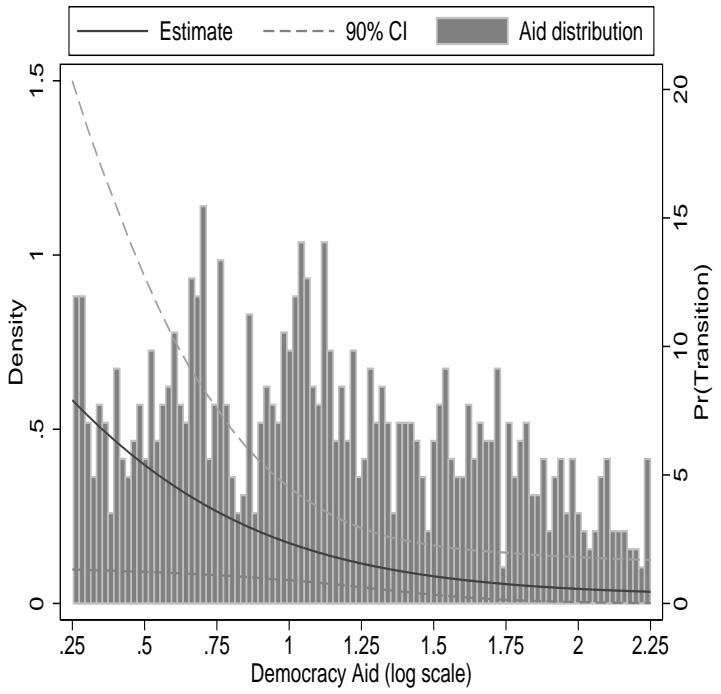

(b) Democracy aid \& electoral misconduct

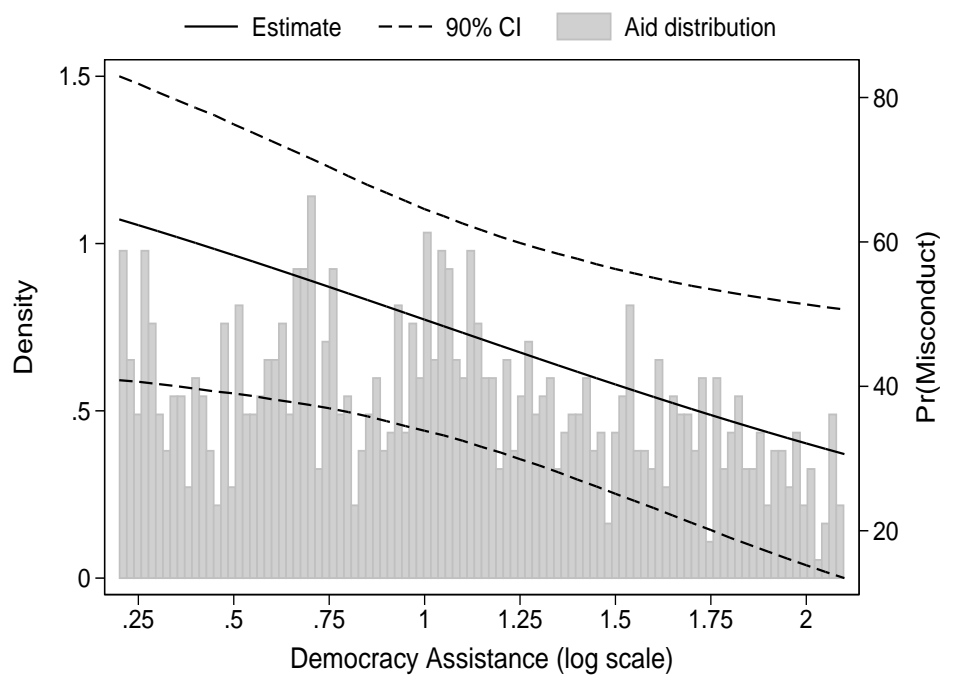

Figure 3: Foreign aid and democratic consolidation. Top panel shows the substantive effect of foreign aid on multiparty transition and failure. Horizontal axes measure aid and vertical axes represent the simulated risk of transition or failure. Shaded histograms are the distribution of aid in the sample. All control variables set at within-sample means or medians. Bottom panel shows substantive relationship between democracy aid and electoral misconduct. Years: 1989-2008. 


\title{
Foreign Aid Allocation Tactics and Democratic Change in Africa*
}

\author{
Simone Dietrich and Joseph Wright
}

May 2014

\begin{abstract}
Over the past two decades, donors increasingly link foreign aid to democracy objectives in Africa. This study investigates whether and how foreign aid influences specific outcomes associated with democratic transition and consolidation. Using an instrumental variables approach for the period from 1989 to 2008, we show that economic aid increases the likelihood of transition to multiparty politics, while democracy aid furthers democratic consolidation by reducing the incidence of multiparty failure and electoral misconduct. However, we find little evidence that either economic or democracy aid influences opposition support in multiparty elections. These findings have implications for how understanding how donors allocate aid and the political consequences of foreign assistance in Africa.
\end{abstract}

*The authors thank Faisal Ahmed, David Bearce, Michael Bernhard, Sona Golder, Florian Hollenbach, Jonathan Kriekhaus, Staffan Lindberg, Helen Milner, Danielle Resnick, Ignacio SanchezCuenca, Nicolas van de Walle, three anonymous reviewers as well as participants at the United Nations University-WIDER Workshop on "Aid and Democracy in Africa", the Visions in Methodology Conference, the 2012 European Political Studies Association Conference, the 2013 Duke University Workshop "Frontiers in Comparative Political Economy", and seminar participants at the University of Florida. Simone Dietrich thanks the Niehaus Center for Globalization and Governance at Princeton University for financial support. Replication materials can be found at: WWW. simone-dietrich.com. 


\section{Appendix A: Data}

Table A-1: Multipartyism

\begin{tabular}{|c|c|c|c|c|c|}
\hline Country & Start & End & Country & Start & End \\
\hline Angola & 1993 & censored & Liberia & 1986 & 1990 \\
\hline Benin & 1992 & censored & Liberia & 1998 & 2002 \\
\hline Botswana & $1967^{\dagger}$ & censored & Liberia & 2006 & censored \\
\hline Burkina Faso & 1993 & censored & Madagascar & 1994 & censored \\
\hline Burundi & 1994 & 1994 & Malawi & 1995 & censored \\
\hline Burundi & 2006 & censored & Mali & 1993 & censored \\
\hline Cameroon & 1993 & censored & Mauritania & 1993 & 2005 \\
\hline Cape Verde & 1992 & censored & Mauritania & 2007 & 2008 \\
\hline Central African Rep. & 1994 & 2003 & Mauritius & $1969^{\dagger}$ & censored \\
\hline Central African Rep. & 2006 & censored & Mozambique & 1995 & censored \\
\hline Chad & 1998 & censored & Namibia & 1995 & censored \\
\hline Comoros & 1993 & 1996 & Niger & 1994 & 1996 \\
\hline Comoros & 2005 & censored & Niger & 1997 & 1999 \\
\hline Congo Br. & 1993 & 1997 & Niger & 2000 & censored \\
\hline Congo Br. & 2003 & censored & Nigeria & 1993 & 1993 \\
\hline Côte d'Ivoire & 1991 & 1999 & Nigeria & 2000 & censored \\
\hline Côte d'Ivoire & 2001 & censored & Rwanda & 2004 & censored \\
\hline Congo DR & 2007 & censored & São Tome & 1992 & censored \\
\hline Equatorial Guinea & 1994 & censored & Senegal & $1979^{\dagger}$ & censored \\
\hline Ethiopia & 1996 & censored & Seychelles & 1994 & censored \\
\hline Gabon & 1991 & censored & Sierra Leone & 1997 & 1997 \\
\hline Gambia & $1967^{\dagger}$ & 1994 & Sierra Leone & 2003 & censored \\
\hline Gambia & 1998 & censored & South Africa & 1994 & censored \\
\hline Ghana & 1997 & censored & Sudan & $1987^{\dagger}$ & 1989 \\
\hline Guinea & 1996 & censored & Tanzania & 1996 & censored \\
\hline Guinea-Bissau & 1995 & 2003 & Togo & 1995 & censored \\
\hline Guinea-Bissau & 2005 & censored & Uganda & 2007 & censored \\
\hline Kenya & 1993 & censored & Zambia & 1992 & censored \\
\hline Lesotho & 1999 & censored & Zimbabwe & $1981^{\dagger}$ & censored \\
\hline
\end{tabular}

Start year coded for first year when multipartyism is observed on January 1; this is typically the year after the first multiparty election. ${ }^{\dagger}$ indicates leftcensored at 1989; censored $\equiv$ right-censored in 2008. 
Table A-2: Multiparty failure events

\begin{tabular}{|c|c|c|}
\hline Country & Date & Event description \\
\hline Burundi & 10 September 1994 & $\begin{array}{l}\text { Frodebu agrees to Government Convention to dampen threat of violence. The } \\
\text { institutional change created a governing body, the Convention, that superceded } \\
\text { the } 1992 \text { constitution and ended Frodebu's defacto } 1993 \text { legislative victory. } \\
\text { Reyntjens }(2009,37) \text { writes, "the constitution was shelved and the outcome of } \\
\text { both the presidential and parliamentary elections was swept aside as the president } \\
\text { and parliament were placed under the trusteeship of an unconstitutional body." }\end{array}$ \\
\hline Central African Rep. & 15 March 2003 & $\begin{array}{l}\text { Bozizé coup (Debos 2008, 229). His troops took Bangui, suspended the } \\
\text { constitution, dissolved the National Assembly, and the elected leader (Patassé) fled. }\end{array}$ \\
\hline Comoros & 1 December 1996 & $\begin{array}{l}\text { The } 1996 \text { legislative elections were boycotted by opposition parties. Only } 3 \text { of } \\
43 \text { contested seats won by an alternative party which supported the ruling RND } \\
\text { (Inter-parliamentary Union, 1996). }\end{array}$ \\
\hline Congo-Brazzaville & 14 October 1997 & $\begin{array}{l}\text { Sassou-Nguesso's militia, backed by Angolan troops, ousted the Lissouba } \\
\text { government from the presidential palace (Clark 1998, 35). Sassou-Nguesso } \\
\text { elected a transition advisory legislature in } 1998 \text { and announced a transition to } \\
\text { democracy but no new legislature was elected. }\end{array}$ \\
\hline Côte d'Ivoire & 24 Demember 1999 & $\begin{array}{l}\text { Gen. Gueï ousts the Bédié government. Gueï amends the constitution in } 2000 \\
\text { to exclude Outtara from the presidential contest (Daddieh 2001, 18). Guë } \\
\text { declares himself winner of the October } 2000 \text { elections, despite losing the vote. }\end{array}$ \\
\hline Gambia & 22 July 1994 & $\begin{array}{l}\text { The Armed Forces Provisional Ruling Council (AFPRC) seized power in a military } \\
\text { coup, deposing the government of Sir Dawda Jawara. Lieutenant Jammeh, } \\
\text { chairman of the AFPRC, suspended the Constitution, banned opposition parties, } \\
\text { and held flawed elections in } 1996 \text { and } 1997 \text { (Saine 2002, 168). }\end{array}$ \\
\hline Guinea-Bissau & 14 September 2003 & $\begin{array}{l}\text { Coup ousts Yala. President Yala dissolves Parliament on } 15 \text { November 2012, } \\
\text { promises and then postpones new elections (Election Guide; Malan 2005, 13). } \\
\text { Transitional government under a military junta holds new elections in } 2005 \text {. }\end{array}$ \\
\hline Liberia & 9 September 1990 & $\begin{array}{l}\text { Doe's government toppled when Prince Johnson's rebel forces kill Doe and capture } \\
\text { Monrovia. An international interim government put in place, but Taylor controlled } \\
\text { most of the territory (Reno 1999, 93). }\end{array}$ \\
\hline Liberia & 2 April 2002 & $\begin{array}{l}\text { Elections that were scheduled for } 2003 \text { never took place. A ban on political parties } \\
\text { took effect on } 2 \text { April } 2002 \text { under February-September State of Emergency } \\
\text { (Outram 2003, 604). }\end{array}$ \\
\hline Mauritania & 3 August 2005 & $\begin{array}{l}\text { President Taya was deposed in a bloodless coup (N'Diaye 2006). The ruling military } \\
\text { council (CMJD) led by Colonel Vall dissolved Parliament (Pazzanita 2008, 132). } \\
\text { New Constituent Assembly elected in November/December } 2006 \text {. }\end{array}$ \\
\hline Mauritania & 6 August 2008 & $\begin{array}{l}\text { President Abdallahi was overthrown in a bloodless coup. The country was officially } \\
\text { run by a } 12 \text {-member High State Council (HSC) composed entirely of military } \\
\text { officers (N'Diaye 2009). }\end{array}$ \\
\hline Niger & 27 January 1996 & $\begin{array}{l}\text { Baré Maïnassara coup replaces President Mahamane Ousmane. The ruling } \\
\text { military council (Conseil de Salut National) suspended the Constitution and political } \\
\text { parties, and dissolved the National Assembly (Englebert 2003,794). }\end{array}$ \\
\hline Niger & 9 April 1999 & $\begin{array}{l}\text { Maïnassara assassinated by members of his predisential guard. Prime Minister } \\
\text { Mayaki dissolved the assembly and political parties and two days later the military } \\
\text { junta (CRN) led by Gen. Wanke "suspended the constitution and formally dissolved } \\
\text { the government" (Political Handbook of the World, 2012). }\end{array}$ \\
\hline Nigeria & 16 June 1993 & $\begin{array}{l}\text { Babangida via the National Election Council (NEC) annuls } 1993 \text { presidential election. } \\
\text { Babangida promises new elections (twice) but Abacha forces him to resign in } \\
\text { November } 1993 \text { (Political Handbook of the World, 2012). }\end{array}$ \\
\hline Sierra Leone & 25 May 1997 & $\begin{array}{l}\text { The Armed Forces Revolutionary Council (AFRC), led by Maj. Johnny Paul Koroma, } \\
\text { overthrow President Kabbah (Reno 1999, 138). }\end{array}$ \\
\hline Sudan & 30 June 1989 & $\begin{array}{l}\text { Coup led by Col al-Bashir and an Islamist faction of the military ousted the elected } \\
\text { government (Burr and Collins 2003, 1). }\end{array}$ \\
\hline
\end{tabular}


Table A-3: Electoral misconduct during election years

\begin{tabular}{|c|c|c|c|c|c|c|c|c|}
\hline Country & Year & Misconduct & Country & Year & Misconduct & Country & Year & Misconduct \\
\hline Angola & 1992 & 1 & Gabon & 1990 & 1 & Mauritania & 2006 & 0 \\
\hline Angola & 2008 & 1 & Gabon & 1993 & 1 & Mauritania & 2007 & 1 \\
\hline Benin & 1991 & 1 & Gabon & 1996 & 0 & Mauritius & 1991 & 0 \\
\hline Benin & 1995 & 0 & Gabon & 1997 & 0 & Mauritius & 1995 & 0 \\
\hline Benin & 1996 & 0 & Gabon & 1998 & 0 & Mauritius & 2000 & 0 \\
\hline Benin & 1999 & 0 & Gabon & 2001 & 0 & Mauritius & 2005 & 0 \\
\hline Benin & 2001 & 0 & Gabon & 2005 & 0 & Mozambique & 1994 & 0 \\
\hline Benin & 2003 & 1 & Gabon & 2006 & 0 & Mozambique & 1999 & 0 \\
\hline Benin & 2006 & 0 & Gambia & 1992 & 0 & Mozambique & 2004 & 0 \\
\hline Benin & 2007 & 0 & Gambia & 1997 & 0 & Namibia & 1994 & 0 \\
\hline Botswana & 1989 & 0 & Gambia & 2001 & 1 & Namibia & 1999 & 0 \\
\hline Botswana & 1994 & 0 & Gambia & 2002 & 0 & Namibia & 2004 & 0 \\
\hline Botswana & 1999 & 0 & Gambia & 2006 & 0 & Niger & 1993 & 1 \\
\hline Botswana & 2004 & 0 & Gambia & 2007 & 0 & Niger & 1995 & 0 \\
\hline Burkina Faso & 1992 & 0 & Ghana & 1996 & 1 & Niger & 2004 & 0 \\
\hline Burkina Faso & 1997 & 0 & Ghana & 2000 & 1 & Nigeria & 1992 & 1 \\
\hline Burkina Faso & 1998 & 0 & Ghana & 2004 & 1 & Nigeria & 1999 & 1 \\
\hline Burkina Faso & 2002 & 0 & Ghana & 2008 & 0 & Nigeria & 2003 & 1 \\
\hline Burkina Faso & 2005 & 0 & Guinea & 1995 & 1 & Nigeria & 2007 & 1 \\
\hline Burkina Faso & 2007 & 0 & Guinea & 1998 & 1 & Rwanda & 2003 & 1 \\
\hline Burundi & 1993 & 0 & Guinea & 2002 & 0 & Rwanda & 2008 & 0 \\
\hline Burundi & 2005 & 0 & Guinea & 2003 & 1 & Senegal & 1993 & 1 \\
\hline Cameroon & 1992 & 1 & Guinea-Bissau & 1994 & 0 & Senegal & 1998 & 1 \\
\hline Cameroon & 1997 & 1 & Guinea-Bissau & 1999 & 1 & Senegal & 2000 & 0 \\
\hline Cameroon & 2002 & 0 & Guinea-Bissau & 2000 & 1 & Senegal & 2001 & 0 \\
\hline Cameroon & 2004 & 0 & Guinea-Bissau & 2004 & 0 & Senegal & 2007 & 0 \\
\hline Cameroon & 2007 & 0 & Guinea-Bissau & 2005 & 0 & Sierra Leone & 1996 & 1 \\
\hline Central African Republic & 1993 & 0 & Guinea-Bissau & 2008 & 1 & Sierra Leone & 2002 & 0 \\
\hline Central African Republic & 1998 & 0 & Kenya & 1992 & 1 & Sierra Leone & 2007 & 1 \\
\hline Central African Republic & 1999 & 1 & Kenya & 1994 & 1 & South Africa & 1994 & 1 \\
\hline Central African Republic & 2005 & 1 & Kenya & 1997 & 1 & South Africa & 1999 & 0 \\
\hline Chad & 1997 & 0 & Kenya & 2002 & 1 & South Africa & 2004 & 0 \\
\hline Chad & 2001 & 0 & Kenya & 2007 & 1 & Tanzania & 1995 & 0 \\
\hline Chad & 2002 & 0 & Lesotho & 1998 & 1 & Tanzania & 2000 & 0 \\
\hline Chad & 2006 & 0 & Lesotho & 2002 & 0 & Tanzania & 2005 & 0 \\
\hline Comoros & 1992 & 1 & Lesotho & 2007 & 1 & Togo & 1994 & 1 \\
\hline Comoros & 1993 & 1 & Liberia & 1997 & 0 & Togo & 1998 & 1 \\
\hline Comoros & 2004 & 0 & Liberia & 2005 & 0 & Togo & 1999 & 0 \\
\hline Comoros & 2006 & 0 & Madagascar & 1993 & 0 & Togo & 2002 & 0 \\
\hline Congo & 1992 & 0 & Madagascar & 1996 & 0 & Togo & 2003 & 1 \\
\hline Congo & 1993 & 1 & Madagascar & 1998 & 0 & Togo & 2005 & 1 \\
\hline Congo & 2002 & 1 & Madagascar & 2001 & 1 & Togo & 2007 & 0 \\
\hline Congo & 2007 & 0 & Madagascar & 2002 & 0 & Uganda & 2006 & 1 \\
\hline Côte d'Ivoire & 1990 & 1 & Madagascar & 2006 & 1 & Zambia & 1991 & 0 \\
\hline Côte d'Ivoire & 1995 & 1 & Madagascar & 2007 & 1 & Zambia & 1995 & 0 \\
\hline Côte d'Ivoire & 2000 & 1 & Malawi & 1994 & 1 & Zambia & 1996 & 1 \\
\hline Côte d'Ivoire & 2001 & 1 & Malawi & 1999 & 1 & Zambia & 2001 & 1 \\
\hline Democratic Republic of Congo & 2006 & 1 & Malawi & 2004 & 0 & Zambia & 2006 & 0 \\
\hline Equatorial Guinea & 1993 & 1 & Mali & 1992 & 0 & Zambia & 2008 & 0 \\
\hline Equatorial Guinea & 1996 & 1 & Mali & 1997 & 1 & Zimbabwe & 1990 & 1 \\
\hline Equatorial Guinea & 1999 & 1 & Mali & 2002 & 0 & Zimbabwe & 1995 & 1 \\
\hline Equatorial Guinea & 2002 & 1 & Mali & 2007 & 0 & Zimbabwe & 1996 & 0 \\
\hline Equatorial Guinea & 2004 & 1 & Mauritania & 1992 & 1 & Zimbabwe & 2000 & 1 \\
\hline Equatorial Guinea & 2008 & 1 & Mauritania & 1996 & 1 & Zimbabwe & 2002 & 1 \\
\hline Ethiopia & 1995 & 1 & Mauritania & 1997 & 0 & Zimbabwe & 2005 & 1 \\
\hline Ethiopia & 2000 & 1 & Mauritania & 2001 & 1 & Zimbabwe & 2008 & 1 \\
\hline Ethiopia & 2005 & 1 & Mauritania & 2003 & 1 & & & \\
\hline
\end{tabular}

Multiparty elections years: 1989-2008. Electoral misconduct source: NELDA13, NELDA 15, NELDA 31 and NELDA 33 from NELDA version 3.0, Hyde and Marinov (2012). 


\section{Economic and development policy and planning}

Macro-economic, fiscal and monetary policy and planning

Institutional capacity building, Government

Support to other ministries and government departments when sector cannot be specified Development planning and preparation of structural reforms

\section{Public sector financial management}

Improving financial management systems

Tax assessment procedures

Measures against waste, fraud and corruption

Legal and judicial development

Constitutional development, legal drafting

Institutional strengthening of legal and judicial systems

Legal training and education

Legal advice and services

Crime prevention

\section{Government administration}

General government services not elsewhere specified

Systems of government

Civil service reform

Government infrastructure

\section{Strengthening civil society}

Strengthening civil society, activity unspecified or does not fit elsewhere in group

Community participation and development

Cooperatives

Grassroots organizations

Other participatory planning and decision making procedures and institutions

Elections

Human rights

Free flow of information

Women's equality organizations and institutions

\section{Conflict prevention and resolution, peace and security}

Security system management and reform

Other security assistance

\section{Civilian peace-building, conflict prevention and resolution}

\section{Support for civilian peace-building activities}

Post-conflict peace-building (UN)

UN post-conflict peace-building activities

Reintegration and small arms, light weapons (SALW) control

Reintegration of demobilised military personnel into the economy

Conversion of production facilities from military to civilian outputs

Assistance to control, prevent and/or reduce the proliferation of SALW

Land mine clearance

Explosive mine removal

Child soldiers (Prevention and demobilisation)

Support to prevent the recruitment of child soldiers4

Support to demobilize child soldiers 


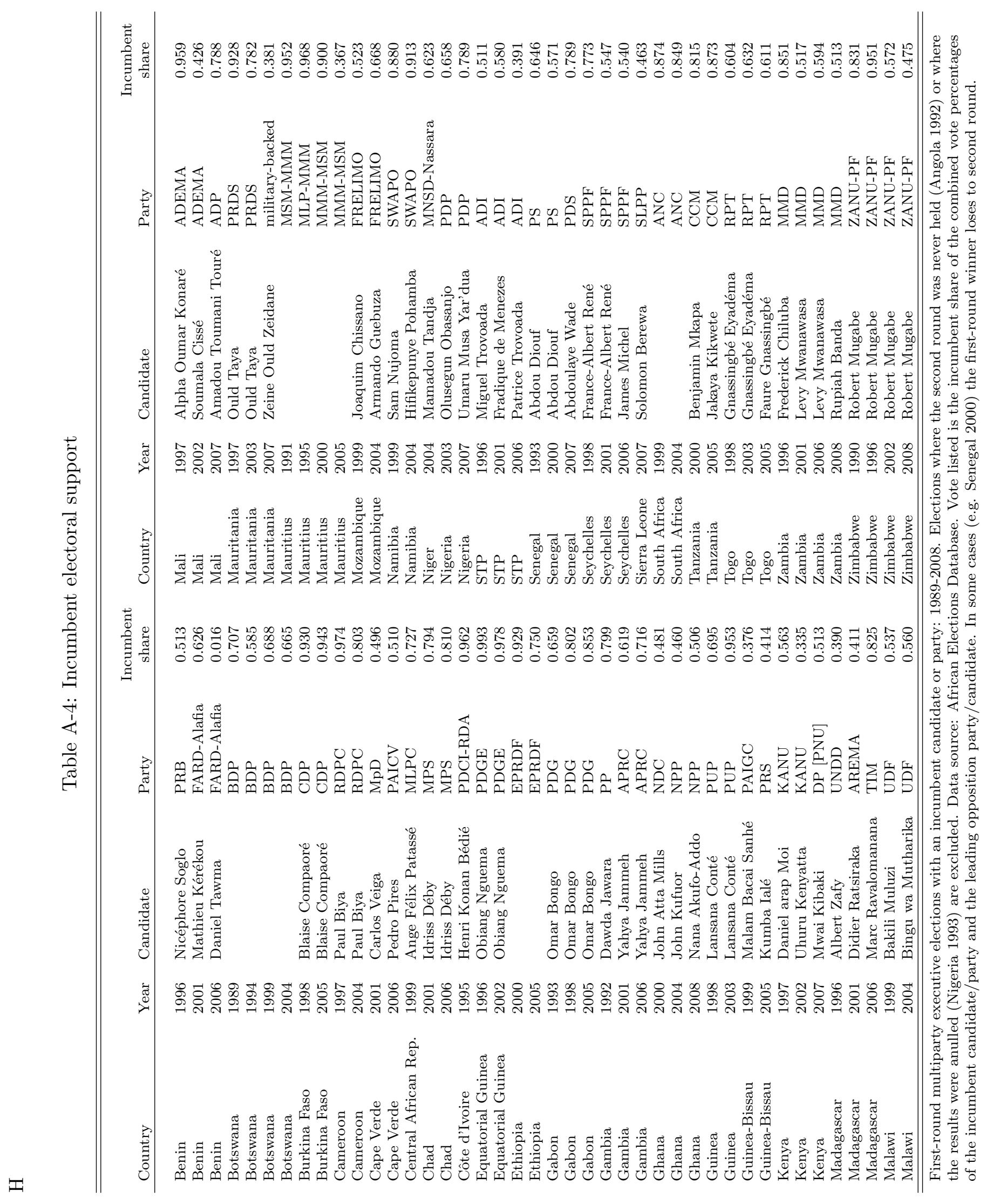


Table A-6: Summary statistics, Table 1

\begin{tabular}{lccccc}
\hline \hline \multicolumn{1}{c}{ Variable } & Mean & Std. Dev. & Min. & Max. & N \\
\hline Multiparty & 0.12 & 0.34 & 0 & 1 & 370 \\
Economic aid & 3.7 & 1 & 0.2 & 6.4 & 370 \\
Democracy aid & 0.9 & 0.7 & 0 & 2.9 & 370 \\
Log GDP pc & 6.9 & 0.8 & 4.8 & 9.6 & 370 \\
Log population & 8.6 & 1.5 & 4.2 & 11.7 & 370 \\
Civil war & 0.2 & 0.4 & 0 & 1 & 370 \\
Duration & 25.2 & 13.3 & 1 & 50 & 370 \\
Duration $^{2}$ & 809.7 & 620.8 & 1 & 2500 & 370 \\
Duration $^{3}$ & 28301 & 27742.7 & 1 & 125000 & 370 \\
Inflation $_{\text {WiP }}^{2.9}$ & 1.1 & 1 & 7.8 & 370 \\
\hline
\end{tabular}


Table A-7: Summary statistics, Table 2

\begin{tabular}{lccccc}
\hline \hline \multicolumn{1}{c}{ Variable } & Mean & Std. Dev. & Min. & Max. & N \\
\hline Multiparty & 0.97 & 0.16 & 0 & 1 & 583 \\
Economic aid & 3.9 & 0.8 & 0.5 & 6.2 & 583 \\
Democracy aid & 1.3 & 0.7 & 0 & 3.2 & 583 \\
Log GDP pc & 7.2 & 1 & 5.1 & 10.2 & 583 \\
Log population & 8.5 & 1.6 & 4.3 & 11.9 & 583 \\
Civil war & 0.1 & 0.2 & 0 & 1 & 583 \\
Duration & 9.2 & 7.5 & 0 & 39 & 583 \\
Duration $^{2}$ & 141.5 & 229 & 0 & 1521 & 583 \\
Duration $^{3}$ & 2919.2 & 7187.2 & 0 & 59319 & 583 \\
Inflation $_{\text {WiP }}^{2.2}$ & 0.7 & 1.1 & 5.1 & 583 \\
\hline
\end{tabular}


Table A-8: Summary statistics, Table 3

\begin{tabular}{lcccc}
\hline \hline \multicolumn{1}{c}{ Variable } & Mean & Std. Dev. & Min. & Max. \\
\hline Electoral misconduct & 0.47 & 0.50 & 0 & 1 \\
Economic aid & 3.9 & 0.7 & 0.3 & 5.7 \\
Democracy aid & 1.2 & 0.6 & 0 & 3 \\
Log GDP pc & 7.1 & 0.9 & 5.1 & 9.8 \\
Log population & 8.7 & 1.3 & 6 & 11.9 \\
IMF program & 0.5 & 0.4 & 0 & 1 \\
First multiparty election & 0.1 & 0.3 & 0 & 1 \\
Election monitor & 0.9 & 0.3 & 0 & 1 \\
Inflation & 2.3 & 0.8 & 1.3 & 5.1 \\
WiP & 19.5 & 4 & 7 & 25.7 \\
\hline \multicolumn{1}{c}{$\mathrm{N}$} & & \multicolumn{3}{c}{} \\
\end{tabular}


Table A-9: Summary statistics, Table 4

\begin{tabular}{lcccc}
\hline \hline \multicolumn{1}{c}{ Variable } & Mean & Std. Dev. & Min. & Max. \\
\hline Opp vote share & -1 & 1.3 & -4.9 & 4.1 \\
Economic aid & 4 & 0.8 & 2.3 & 5.9 \\
Democracy aid & 1.3 & 0.7 & 0.1 & 3 \\
Log GDP pc & 7.3 & 1.1 & 5.1 & 10 \\
Log population & 8.5 & 1.7 & 4.3 & 11.9 \\
Growth & 3.5 & 7.4 & -14.6 & 38.2 \\
IMF program & 0.6 & 0.5 & 0 & 1 \\
Inflation & 2.1 & 0.6 & 1.1 & 4.7 \\
WiP & 20.4 & 3.5 & 10 & 25.7 \\
\hline \multicolumn{1}{c}{$\mathrm{N}$} & & \multicolumn{3}{c}{}
\end{tabular}


Appendix B: Additional results 
Table B-1: Additional tests for multiparty transition

\begin{tabular}{|c|c|c|c|c|c|c|c|c|c|c|c|c|c|c|c|}
\hline & $(1)^{a}$ & $(2)^{b}$ & $(3)^{c}$ & $(4)^{d}$ & $(5)^{e}$ & (6) & $(7)$ & $(8)$ & $(9)$ & $(10)$ & $(11)$ & $(12)$ & (13) & $(14)$ & $(15)$ \\
\hline Econ aid & $\begin{array}{c}0.083^{* *} \\
(0.04)\end{array}$ & $\begin{array}{c}0.117^{* *} \\
(0.03)\end{array}$ & $\begin{array}{c}0.127^{*} \\
(0.07)\end{array}$ & $\begin{array}{c}0.107^{* *} \\
(0.04)\end{array}$ & $\begin{array}{c}0.083^{* *} \\
(0.04)\end{array}$ & $\begin{array}{c}0.094^{* *} \\
(0.04)\end{array}$ & $\begin{array}{c}0.101^{* *} \\
(0.04)\end{array}$ & $\begin{array}{c}0.103^{* *} \\
(0.04)\end{array}$ & $\begin{array}{c}0.110^{* *} \\
(0.04)\end{array}$ & $\begin{array}{c}0.106^{* *} \\
(0.04)\end{array}$ & $\begin{array}{c}0.104^{* *} \\
(0.04)\end{array}$ & $\begin{array}{c}0.106^{* *} \\
(0.04)\end{array}$ & $\begin{array}{c}0.106^{* *} \\
(0.04)\end{array}$ & $\begin{array}{c}0.107^{* *} \\
(0.04)\end{array}$ & $\begin{array}{c}0.109^{* *} \\
(0.04)\end{array}$ \\
\hline Log GDP pc & $\begin{array}{l}0.003 \\
(0.02)\end{array}$ & $\begin{array}{c}0.004 \\
(0.02)\end{array}$ & $\begin{array}{l}0.045 \\
(0.09)\end{array}$ & $\begin{array}{l}0.005 \\
(0.02)\end{array}$ & & $\begin{array}{c}0.001 \\
(0.02)\end{array}$ & $\begin{array}{l}-0.018 \\
(0.03)\end{array}$ & $\begin{array}{l}0.007 \\
(0.02)\end{array}$ & $\begin{array}{l}0.004 \\
(0.02)\end{array}$ & $\begin{array}{c}-0.033^{* *} \\
(0.02)\end{array}$ & $\begin{array}{l}0.002 \\
(0.02)\end{array}$ & $\begin{array}{r}-0.001 \\
(0.03)\end{array}$ & $\begin{array}{c}0.004 \\
(0.02)\end{array}$ & $\begin{array}{r}-0.019 \\
(0.03)\end{array}$ & $\begin{array}{c}0.011 \\
(0.02)\end{array}$ \\
\hline Log pop & $\begin{array}{l}0.031^{*} \\
(0.02)\end{array}$ & $\begin{array}{c}0.044^{* *} \\
(0.02)\end{array}$ & $\begin{array}{c}0.518^{*} \\
(0.30)\end{array}$ & $\begin{array}{c}0.043^{* *} \\
(0.02)\end{array}$ & & $\begin{array}{c}0.045^{* *} \\
(0.02)\end{array}$ & $\begin{array}{l}0.026 \\
(0.02)\end{array}$ & $\begin{array}{c}0.039^{* *} \\
(0.02)\end{array}$ & $\begin{array}{c}0.042^{* *} \\
(0.02)\end{array}$ & $\begin{array}{l}0.004 \\
(0.02)\end{array}$ & $\begin{array}{c}0.041^{* *} \\
(0.02)\end{array}$ & $\begin{array}{c}0.044^{* *} \\
(0.02)\end{array}$ & $\begin{array}{c}0.042^{* *} \\
(0.02)\end{array}$ & $\begin{array}{c}0.000 \\
(0.02)\end{array}$ & $\begin{array}{c}0.046^{* *} \\
(0.02)\end{array}$ \\
\hline Civil war & $\begin{array}{c}-0.112^{* *} \\
(0.04)\end{array}$ & $\begin{array}{c}-0.108^{* *} \\
(0.04)\end{array}$ & $\begin{array}{r}-0.046 \\
(0.06)\end{array}$ & $\begin{array}{c}-0.110^{* *} \\
(0.04)\end{array}$ & & $\begin{array}{c}-0.124^{* *} \\
(0.04)\end{array}$ & $\begin{array}{c}-0.100^{* *} \\
(0.04)\end{array}$ & $\begin{array}{c}-0.110^{* *} \\
(0.04)\end{array}$ & $\begin{array}{c}-0.110^{* *} \\
(0.04)\end{array}$ & $\begin{array}{c}-0.094^{* *} \\
(0.04)\end{array}$ & $\begin{array}{c}-0.109^{* *} \\
(0.04)\end{array}$ & $\begin{array}{c}-0.109^{* *} \\
(0.04)\end{array}$ & $\begin{array}{c}-0.110^{* *} \\
(0.04)\end{array}$ & $\begin{array}{c}-0.120^{* *} \\
(0.04)\end{array}$ & $\begin{array}{c}-0.118^{* *} \\
(0.04)\end{array}$ \\
\hline Ethnic frac. & & & & & & $\begin{array}{r}-0.047 \\
(0.08)\end{array}$ & & & & & & & & & \\
\hline Oil rents pc & & & & & & & $\begin{array}{c}0.022 * * \\
(0.01)\end{array}$ & & & & & & & & \\
\hline IMF program & & & & & & & & $\begin{array}{l}0.027 \\
(0.05)\end{array}$ & & & & & & & \\
\hline Growth & & & & & & & & & $\begin{array}{r}-0.000 \\
(0.00)\end{array}$ & & & & & & \\
\hline Trade & & & & & & & & & & $\begin{array}{c}0.045^{* *} \\
(0.01)\end{array}$ & & & & & \\
\hline Intl NGO & & & & & & & & & & & $\begin{array}{l}0.020 \\
(0.09)\end{array}$ & & & & \\
\hline Dom. NGO & & & & & & & & & & & & $\begin{array}{l}0.042 \\
(0.09)\end{array}$ & & & \\
\hline Migrant stock & & & & & & & & & & & & & $\begin{array}{l}-0.004 \\
(0.01)\end{array}$ & & \\
\hline IO member & & & & & & & & & & & & & & $\begin{array}{c}0.008^{* *} \\
(0.00)\end{array}$ & \\
\hline Alliance & & & & & & & & & & & & & & & $\begin{array}{c}0.128^{* *} \\
(0.03)\end{array}$ \\
\hline (Intercept) & $\begin{array}{r}-0.297 \\
(0.32) \\
\end{array}$ & $\begin{array}{c}-0.513^{*} \\
(0.28) \\
\end{array}$ & & $\begin{array}{r}-0.469 \\
(0.32) \\
\end{array}$ & $\begin{array}{c}-0.041 \\
(0.11) \\
\end{array}$ & $\begin{array}{r}-0.379 \\
(0.33) \\
\end{array}$ & $\begin{array}{c}-0.183 \\
(0.33) \\
\end{array}$ & $\begin{array}{r}-0.452 \\
(0.30)\end{array}$ & $\begin{array}{r}-0.467 \\
(0.35) \\
\end{array}$ & $\begin{array}{c}-0.181 \\
(0.25) \\
\end{array}$ & $\begin{array}{l}-0.439 \\
(0.30) \\
\end{array}$ & $\begin{array}{c}-0.454 \\
(0.30)\end{array}$ & $\begin{array}{r}-0.451 \\
(0.30) \\
\end{array}$ & $\begin{array}{r}-0.398 \\
(0.32) \\
\end{array}$ & $\begin{array}{c}-0.583^{* *} \\
(0.29) \\
\end{array}$ \\
\hline F-statistic & 19.8 & 15.1 & 10.0 & 20.4 & 14.8 & 16.6 & 20.8 & 26.3 & 25.6 & 22.5 & 18.9 & 19.5 & 21.8 & 23.6 & 23.7 \\
\hline C (p-value) & & 0.46 & & 0.36 & 0.37 & 0.72 & 0.26 & 0.30 & 0.23 & 0.35 & 0.23 & 0.29 & 0.21 & 0.26 & 0.30 \\
\hline Countries & 44 & 44 & 44 & 42 & 44 & 39 & 42 & 44 & 44 & 44 & 44 & 44 & 44 & 44 & 44 \\
\hline Observations & 370 & 370 & 370 & 362 & 370 & 332 & 362 & 370 & 369 & 370 & 370 & 370 & 370 & 370 & 370 \\
\hline
\end{tabular}

${ }^{*} \mathrm{p}<0.10 ;{ }^{* *} \mathrm{p}<0.05$. IV models with clustered standard errors in parentheses. Duration polynomials included in all models but not reported. $a \equiv$ only Lewbel instruments (no Inflation); $b \equiv$ Inflation + Lewbel instruments based on duration polynomials; $c \equiv$ two-way fixed effects (time period and country); $d \equiv$ drop island countries; $e \equiv$ no control variables. 
Table B-2: Additional tests for multiparty failure

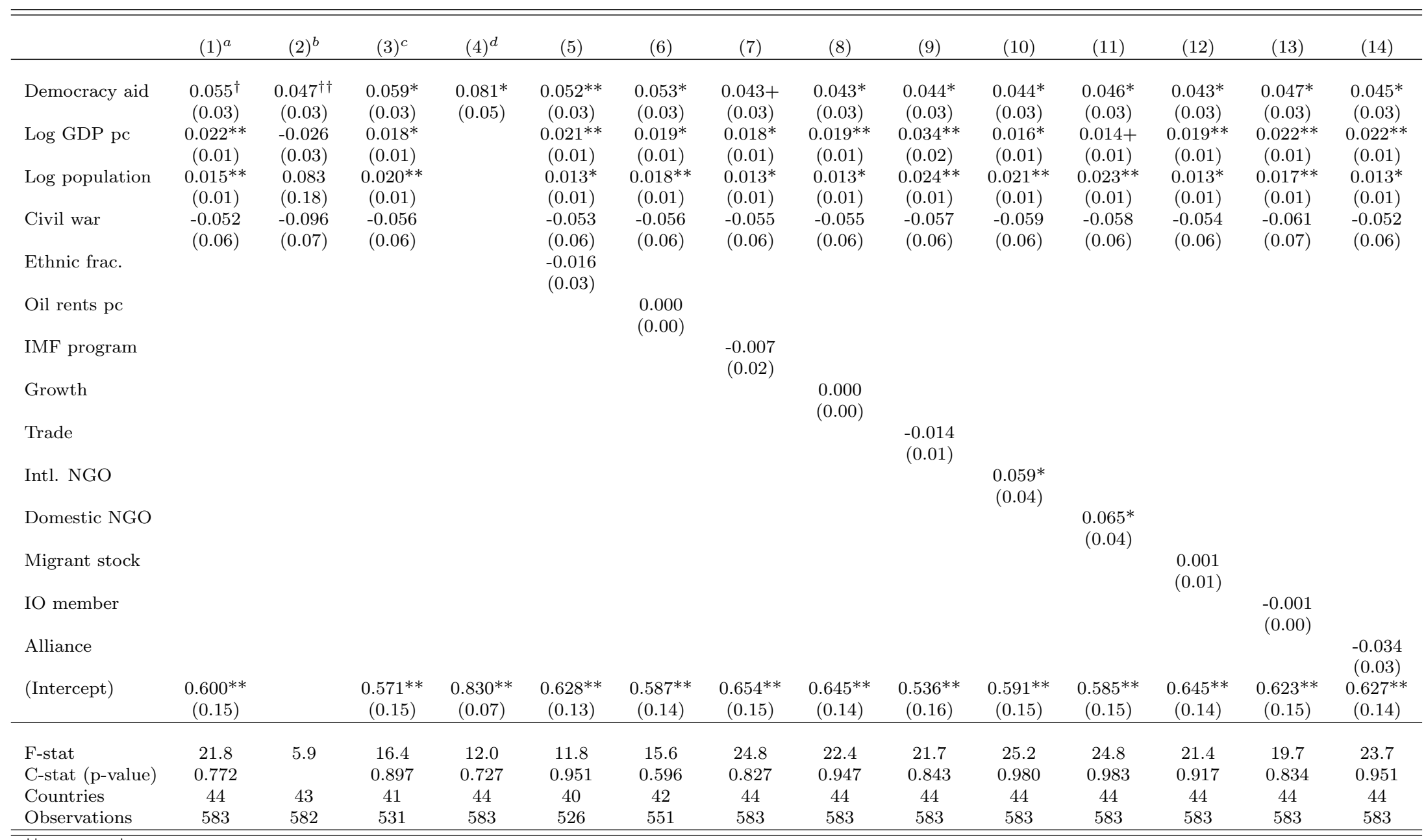

${ }^{\dagger \dagger} \mathrm{p}<0.18 ;{ }^{\dagger} \mathrm{p}<0.11 ;^{*} \mathrm{p}<0.10 ;^{* *} \mathrm{p}<0.05$. IV models with clustered standard errors in parentheses. Duration polynomials included in all models but not reported.
$a \equiv$ Inflation + Lewbel instruments based on duration polynomials; $b \equiv$ two-way fixed effects (time period and country); $c \equiv$ drop island countries; $d \equiv$ no control variables. 
Table B-3: Linear probability models with unit FE

\begin{tabular}{|c|c|c|c|c|c|c|}
\hline & $(1)$ & $(2)$ & $(3)$ & $(4)$ & $(5)$ & (6) \\
\hline Economic aid & $\begin{array}{l}0.065 \\
(0.04)\end{array}$ & $\begin{array}{c}0.123^{* *} \\
(0.04)\end{array}$ & $\begin{array}{c}0.068^{*} \\
(0.03)\end{array}$ & & & \\
\hline Democracy aid & & & & $\begin{array}{c}0.050^{* *} \\
(0.02)\end{array}$ & $\begin{array}{c}0.051^{* *} \\
(0.02)\end{array}$ & $\begin{array}{c}0.039^{*} \\
(0.02)\end{array}$ \\
\hline (Intercept) & $\begin{array}{l}-0.031 \\
(0.17) \\
\end{array}$ & $\begin{array}{c}-0.589^{* *} \\
(0.20) \\
\end{array}$ & $\begin{array}{c}-1.067^{* *} \\
(0.13) \\
\end{array}$ & $\begin{array}{c}0.800^{* *} \\
(0.14) \\
\end{array}$ & $\begin{array}{c}0.889^{* *} \\
(0.04) \\
\end{array}$ & $\begin{array}{c}0.926^{* *} \\
(0.09) \\
\end{array}$ \\
\hline Country FE & $\mathrm{Y}$ & $\mathrm{Y}$ & $\mathrm{Y}$ & $\mathrm{Y}$ & $\mathrm{Y}$ & $\mathrm{Y}$ \\
\hline Year FE & $\mathrm{Y}$ & $\mathrm{N}$ & $\mathrm{N}$ & $\mathrm{Y}$ & $\mathrm{N}$ & $\mathrm{N}$ \\
\hline Time trend & $\mathrm{N}$ & $\mathrm{Y}$ & $\mathrm{N}$ & $\mathrm{N}$ & $\mathrm{Y}$ & $\mathrm{N}$ \\
\hline Country specific-time trend & $\mathrm{N}$ & $\mathrm{N}$ & $\mathrm{Y}$ & $\mathrm{N}$ & $\mathrm{N}$ & $\mathrm{Y}$ \\
\hline
\end{tabular}

An alternative approach to constructing causal estimates that does not rely on external instruments to identify the "exogenous" variation in foreign aid is to estimate fixed-effects models. This approach assumes that the unit fixed-effect "controls" for unobserved confounders. In our application, we model unit fixed effects in combination with three methods of accounting for a calendar time trend in the data: year fixed effects; a common time trend; and a country-specific time trend. Because we include subtantial cross-section variation in the unit-fixed effects, we drop GDP per capita and population as control variables, but retain the time-varying measure of civil war. To avoid separation issues that arise in a limited dependent variable model, we employ a linear probability model. In all specification reported in Table B-3, the main reported results from Tables 1 (multiparty transition) and 2 (multiparty failure) remain. We cannot employ this approach for the models of electoral misconduct and opposition electoral strength because there are too few observations per cross-section unit to reliably estimate a fixed effects model. 
Table B-4: Additional tests for electoral misconduct

\begin{tabular}{|c|c|c|c|c|c|c|c|c|c|c|c|c|c|}
\hline & $(1)$ & $(2)$ & $(3)$ & $(4)$ & $(5)$ & (6) & $(7)$ & $(8)$ & $(9)$ & $(10)$ & (11) & $(12)^{a}$ & $(13)^{b}$ \\
\hline Democracy aid & $\begin{array}{c}-0.174^{*} \\
(0.10)\end{array}$ & $\begin{array}{c}-0.154^{*} \\
(0.09)\end{array}$ & $\begin{array}{c}-0.170^{*} \\
(0.10)\end{array}$ & $\begin{array}{c}-0.179^{*} \\
(0.10)\end{array}$ & $\begin{array}{c}-0.215^{* *} \\
(0.11)\end{array}$ & $\begin{array}{c}-0.149+ \\
(0.09)\end{array}$ & $\begin{array}{c}-0.200^{* *} \\
(0.09)\end{array}$ & $\begin{array}{c}-0.167^{*} \\
(0.09)\end{array}$ & $\begin{array}{c}-0.172^{*} \\
(0.10)\end{array}$ & $\begin{array}{c}-0.138+ \\
(0.09)\end{array}$ & $\begin{array}{c}-0.186^{*} \\
(0.10)\end{array}$ & $\begin{array}{c}-0.218^{* *} \\
(0.10)\end{array}$ & $\begin{array}{c}-0.146+ \\
(0.10)\end{array}$ \\
\hline Log GDP pc & $\begin{array}{r}-0.055 \\
(0.06)\end{array}$ & $\begin{array}{r}-0.049 \\
(0.06)\end{array}$ & $\begin{array}{r}-0.046 \\
(0.06)\end{array}$ & $\begin{array}{r}-0.055 \\
(0.06)\end{array}$ & $\begin{array}{c}-0.054 \\
(0.06)\end{array}$ & $\begin{array}{c}-0.183 \\
(0.11)\end{array}$ & $\begin{array}{c}-0.111^{* *} \\
(0.05)\end{array}$ & $\begin{array}{l}0.003 \\
(0.08)\end{array}$ & $\begin{array}{r}-0.028 \\
(0.07)\end{array}$ & $\begin{array}{r}-0.062 \\
(0.05)\end{array}$ & $\begin{array}{r}-0.028 \\
(0.06)\end{array}$ & $\begin{array}{r}-0.029 \\
(0.06)\end{array}$ & $\begin{array}{c}-0.052 \\
(0.06)\end{array}$ \\
\hline Log population & $\begin{array}{l}0.019 \\
(0.05)\end{array}$ & $\begin{array}{l}0.033 \\
(0.05)\end{array}$ & $\begin{array}{l}0.024 \\
(0.05)\end{array}$ & $\begin{array}{c}0.023 \\
(0.05)\end{array}$ & $\begin{array}{l}0.034 \\
(0.06)\end{array}$ & $\begin{array}{r}-0.100 \\
(0.09)\end{array}$ & $\begin{array}{c}0.199 * * \\
(0.07)\end{array}$ & $\begin{array}{r}-0.064 \\
(0.10)\end{array}$ & $\begin{array}{l}0.039 \\
(0.05)\end{array}$ & $\begin{array}{c}-0.054 \\
(0.05)\end{array}$ & $\begin{array}{l}0.014 \\
(0.05)\end{array}$ & $\begin{array}{l}0.011 \\
(0.05)\end{array}$ & $\begin{array}{l}0.017 \\
(0.05)\end{array}$ \\
\hline IMF program & $\begin{array}{l}0.004 \\
(0.12)\end{array}$ & $\begin{array}{c}-0.022 \\
(0.12)\end{array}$ & $\begin{array}{l}0.008 \\
(0.13)\end{array}$ & $\begin{array}{l}0.004 \\
(0.13)\end{array}$ & $\begin{array}{c}-0.046 \\
(0.12)\end{array}$ & $\begin{array}{l}0.090 \\
(0.10)\end{array}$ & $\begin{array}{l}0.019 \\
(0.12)\end{array}$ & $\begin{array}{l}-0.027 \\
(0.12)\end{array}$ & $\begin{array}{l}0.044 \\
(0.13)\end{array}$ & $\begin{array}{l}0.031 \\
(0.10)\end{array}$ & $\begin{array}{c}-0.005 \\
(0.12)\end{array}$ & $\begin{array}{l}0.004 \\
(0.13)\end{array}$ & $\begin{array}{l}-0.003 \\
(0.13)\end{array}$ \\
\hline First election & $\begin{array}{l}0.092 \\
(0.11)\end{array}$ & $\begin{array}{l}0.073 \\
(0.11)\end{array}$ & $\begin{array}{l}0.069 \\
(0.12)\end{array}$ & $\begin{array}{l}0.071 \\
(0.12)\end{array}$ & $\begin{array}{l}0.034 \\
(0.12)\end{array}$ & $\begin{array}{l}0.080 \\
(0.11)\end{array}$ & $\begin{array}{l}0.091 \\
(0.11)\end{array}$ & $\begin{array}{l}0.035 \\
(0.12)\end{array}$ & $\begin{array}{l}0.027 \\
(0.11)\end{array}$ & $\begin{array}{l}0.075 \\
(0.11)\end{array}$ & $\begin{array}{l}0.065 \\
(0.12)\end{array}$ & $\begin{array}{l}0.053 \\
(0.12)\end{array}$ & $\begin{array}{l}0.024 \\
(0.12)\end{array}$ \\
\hline Monitor & $\begin{array}{c}-0.034 \\
(0.14)\end{array}$ & $\begin{array}{c}-0.036 \\
(0.13)\end{array}$ & $\begin{array}{c}-0.055 \\
(0.13)\end{array}$ & $\begin{array}{c}-0.058 \\
(0.13)\end{array}$ & $\begin{array}{c}-0.019 \\
(0.15)\end{array}$ & $\begin{array}{c}-0.006 \\
(0.14)\end{array}$ & $\begin{array}{l}-0.055 \\
(0.14)\end{array}$ & $\begin{array}{l}-0.081 \\
(0.13)\end{array}$ & $\begin{array}{c}-0.060 \\
(0.14)\end{array}$ & $\begin{array}{c}-0.014 \\
(0.14)\end{array}$ & $\begin{array}{r}-0.048 \\
(0.13)\end{array}$ & $\begin{array}{c}-0.100 \\
(0.14)\end{array}$ & $\begin{array}{l}-0.027 \\
(0.14)\end{array}$ \\
\hline Expect win & $\begin{array}{l}0.137 \\
(0.09)\end{array}$ & & & & & & & & & & & & \\
\hline Boycott & & $\begin{array}{l}0.161 \\
(0.10)\end{array}$ & & & & & & & & & & & \\
\hline Civil war & & & $\begin{array}{r}-0.007 \\
(0.15)\end{array}$ & & & & & & & & & & \\
\hline Growth & & & & $\begin{array}{l}0.003 \\
(0.01)\end{array}$ & & & & & & & & & \\
\hline Ethinc frac. & & & & & $\begin{array}{l}0.141 \\
(0.25)\end{array}$ & & & & & & & & \\
\hline Trade & & & & & & $\begin{array}{c}0.157^{*} \\
(0.08)\end{array}$ & & & & & & & \\
\hline Intl NGO & & & & & & & $\begin{array}{c}2.838^{* *} \\
(1.08)\end{array}$ & & & & & & \\
\hline Domestic NGO & & & & & & & & $\begin{array}{c}-1.130 \\
(0.90)\end{array}$ & & & & & \\
\hline IO member & & & & & & & & & $\begin{array}{c}-0.004 \\
(0.00)\end{array}$ & & & & \\
\hline Migrant stock & & & & & & & & & & $\begin{array}{c}0.138^{* *} \\
(0.04)\end{array}$ & & & \\
\hline Alliance & & & & & & & & & & & $\begin{array}{c}-0.181 \\
(0.13)\end{array}$ & & \\
\hline (Intercept) & $\begin{array}{l}0.844 \\
(0.65) \\
\end{array}$ & $\begin{array}{l}0.707 \\
(0.61) \\
\end{array}$ & $\begin{array}{l}0.824 \\
(0.65) \\
\end{array}$ & $\begin{array}{l}0.901 \\
(0.65) \\
\end{array}$ & $\begin{array}{l}0.763 \\
(0.68) \\
\end{array}$ & $\begin{array}{c}1.707^{*} \\
(1.03)\end{array}$ & $\begin{array}{l}-0.486 \\
(0.87) \\
\end{array}$ & $\begin{array}{l}1.485 \\
(0.92) \\
\end{array}$ & $\begin{array}{l}0.800 \\
(0.62) \\
\end{array}$ & $\begin{array}{l}1.186^{*} \\
(0.64) \\
\end{array}$ & $\begin{array}{l}0.815 \\
(0.61)\end{array}$ & $\begin{array}{l}0.931 \\
(0.69) \\
\end{array}$ & $\begin{array}{l}0.881 \\
(0.65) \\
\end{array}$ \\
\hline F-statistic & 10.4 & 9.8 & 10.6 & 10.3 & 9.5 & 10.3 & 11.5 & 11.0 & 11.7 & 10.7 & 10.4 & 9.8 & 10.5 \\
\hline C (p-value) & 0.226 & 0.286 & 0.204 & 0.203 & 0.285 & 0.168 & 0.122 & 0.285 & 0.217 & 0.127 & 0.210 & 0.153 & 0.258 \\
\hline Countries & 40 & 40 & 40 & 40 & 38 & 40 & 40 & 40 & 40 & 40 & 40 & 39 & 39 \\
\hline Observations & 170 & 170 & 170. & 170 & 159 & 170 & 170 & 170 & 170 & 170 & 170 & 166 & 158 \\
\hline
\end{tabular}

${ }^{+} \mathrm{p}<0.15^{*} \mathrm{p}<0.10{ }^{* *} \mathrm{p}<0.05$. IV models with clustered standard errors in parentheses. $a \equiv$ drop island countries; $b \equiv$ drop civil war years. 
Table B-5: Opposition vote share of total vote

\begin{tabular}{lcccc}
\hline \hline & & & & \\
& $(1)$ & $(2)$ & $(3)^{a}$ & $(4)^{a}$ \\
\hline & & & & \\
Economic aid & -0.122 & & -0.271 & \\
& $(0.27)$ & & $(0.20)$ & 0.054 \\
Democracy aid & & $0.684^{*}$ & & $(0.27)$ \\
& & $(0.38)$ & & -0.116 \\
Log GDP pc & 0.001 & 0.070 & -0.098 & $(0.13)$ \\
& $(0.12)$ & $(0.15)$ & $(0.11)$ & -0.076 \\
Log population & -0.080 & 0.064 & $-0.179^{* *}$ & $-0.12)$ \\
& $(0.16)$ & $(0.12)$ & $(0.08)$ \\
Growth & -0.034 & $-0.043^{*}$ & -0.012 & -0.014 \\
& $(0.02)$ & $(0.02)$ & $(0.02)$ & $(0.02)$ \\
IMF program & 0.037 & -0.243 & 0.341 & 0.206 \\
& $(0.24)$ & $(0.30)$ & $(0.27)$ & $(0.26)$ \\
(Intercept) & 0.865 & -2.030 & $3.164^{* *}$ & 1.334 \\
& $(2.69)$ & $(2.27)$ & $(1.30)$ & $(1.67)$ \\
\hline & & & & \\
F-statistic & 22.5 & 19.0 & 15.4 & 12.8 \\
C (p-value) & 0.337 & 0.093 & 0.207 & 0.121 \\
Countries & 34 & 34 & 31 & 31 \\
Election years & 84 & 84 & 70 & 70 \\
\hline \hline * p<0.10; ** p<0.05. IV models with clustered stan- \\
dard errors in parentheses. $a \equiv$ Incumbent vote share \\
$<90 \%$.
\end{tabular}

Table B-5 reports result from models that use the largest opposition vote total as a share of the total vote. Initially, we find that Economic aid is associated with lower opposition vote shares, even when dropping the most lopsided elections (column 3). However, this result is much weaker when we include the full set of Lewbel instruments to the increase efficiency of the estimate (the F-statistic increases from 5.7 in column 3 to 15.5 in column 5). The estimate for Economic aid in column 5 can be interpreted to mean that a one-standard deviation increase in economic aid is associated with a roughly 5 percent decrease in opposition vote share, which is statistically significant at the 0.17 level in a sample with only 70 observations. Using the full set of Lewbel instruments to increase the efficiency of the estimate for Democracy aid (column 6) reduces the estimate for this type of aid to almost zero. 
Table B-6: Lagged DV models for opposition vote

\begin{tabular}{|c|c|c|c|c|c|c|}
\hline \multirow[t]{2}{*}{ Opposition vote } & \multicolumn{3}{|c|}{$\underline{\text { Share of 2-party vote }}$} & \multicolumn{3}{|c|}{$\underline{\text { Share of total vote }}$} \\
\hline & $(1)$ & $(2)$ & $(3)^{a}$ & $(4)$ & $(5)$ & $(6)^{a}$ \\
\hline Lag DV & $\begin{array}{c}0.458^{* *} \\
(0.11)\end{array}$ & $\begin{array}{c}0.394^{* *} \\
(0.11)\end{array}$ & $\begin{array}{c}0.209 * * \\
(0.09)\end{array}$ & $\begin{array}{c}0.356^{*} \\
(0.19)\end{array}$ & $\begin{array}{c}0.343^{* *} \\
(0.17)\end{array}$ & $\begin{array}{l}0.155 \\
(0.19)\end{array}$ \\
\hline Economic aid & $\begin{array}{c}-0.012 \\
(0.27)\end{array}$ & & & $\begin{array}{l}0.222 \\
(0.41)\end{array}$ & & \\
\hline Democracy aid & & $\begin{array}{l}0.563 \\
(0.42)\end{array}$ & $\begin{array}{l}0.194 \\
(0.27)\end{array}$ & & $\begin{array}{l}0.476 \\
(0.36)\end{array}$ & $\begin{array}{l}0.206 \\
(0.31)\end{array}$ \\
\hline Log GDP pc & $\begin{array}{l}-0.109 \\
(0.10)\end{array}$ & $\begin{array}{c}-0.002 \\
(0.13)\end{array}$ & $\begin{array}{c}-0.186^{*} \\
(0.11)\end{array}$ & $\begin{array}{l}-0.101 \\
(0.13)\end{array}$ & $\begin{array}{l}0.051 \\
(0.14)\end{array}$ & $\begin{array}{l}-0.116 \\
(0.14)\end{array}$ \\
\hline Log population & $\begin{array}{l}-0.112 \\
(0.10)\end{array}$ & $\begin{array}{l}-0.017 \\
(0.11)\end{array}$ & $\begin{array}{c}-0.113 \\
(0.08)\end{array}$ & $\begin{array}{l}0.003 \\
(0.14)\end{array}$ & $\begin{array}{l}0.022 \\
(0.09)\end{array}$ & $\begin{array}{l}-0.051 \\
(0.09)\end{array}$ \\
\hline Growth & $\begin{array}{c}-0.034^{* *} \\
(0.01)\end{array}$ & $\begin{array}{c}-0.042^{* *} \\
(0.02)\end{array}$ & $\begin{array}{l}-0.021 \\
(0.02)\end{array}$ & $\begin{array}{c}-0.036^{* *} \\
(0.01)\end{array}$ & $\begin{array}{c}-0.045^{* *} \\
(0.02)\end{array}$ & $\begin{array}{l}-0.018 \\
(0.02)\end{array}$ \\
\hline IMF program & $\begin{array}{r}-0.045 \\
(0.41)\end{array}$ & $\begin{array}{r}-0.206 \\
(0.36)\end{array}$ & $\begin{array}{l}-0.115 \\
(0.29)\end{array}$ & $\begin{array}{r}-0.159 \\
(0.50)\end{array}$ & $\begin{array}{l}-0.118 \\
(0.35)\end{array}$ & $\begin{array}{l}-0.025 \\
(0.33)\end{array}$ \\
\hline (Intercept) & $\begin{array}{l}1.708 \\
(1.50)\end{array}$ & $\begin{array}{l}-0.609 \\
(1.97) \\
\end{array}$ & $\begin{array}{l}1.954 \\
(1.28) \\
\end{array}$ & $\begin{array}{l}0.061 \\
(2.20) \\
\end{array}$ & $\begin{array}{l}-0.939 \\
(1.75) \\
\end{array}$ & $\begin{array}{l}1.206 \\
(1.62) \\
\end{array}$ \\
\hline F-statistic & 15.0 & 28.2 & 22.1 & 8.4 & 32.3 & 25.3 \\
\hline Countries & 30 & 30 & 26 & 30 & 30 & 26 \\
\hline Elections & 50 & 50 & 44 & 50 & 50 & 44 \\
\hline
\end{tabular}

${ }^{*} \mathrm{p}<0.10 ;{ }^{* *} \mathrm{p}<0.05$. IV models with clustered standard errors in parentheses.

$a \equiv$ Incumbent vote share $<90 \%$.

Table B-6 reported results from lagged dependent variable models to account for the history of voting in prior elections. The first three columns use the dependent variable reported in the manuscript: the opposition share of the 2-party vote. The latter three columns use the same depedent variable as in Table B-5: all opposition parties' share of the total vote. We find little evidence that aid influences either of these outcomes in the lagged DV models. 
Multiparty transition (1.3)

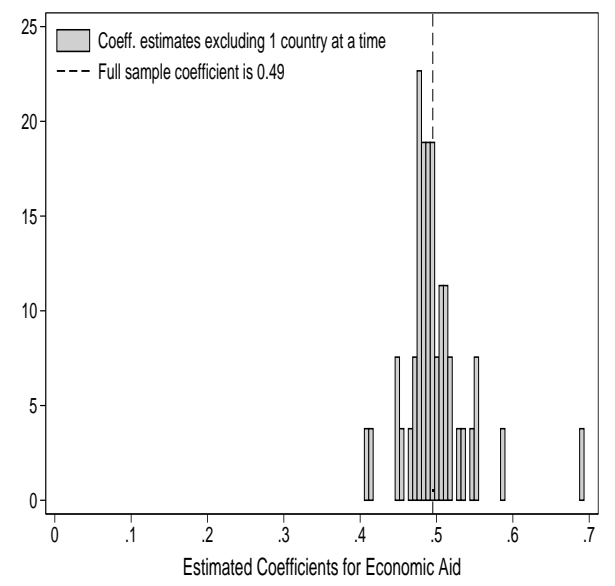

Multiparty failure (2.6)

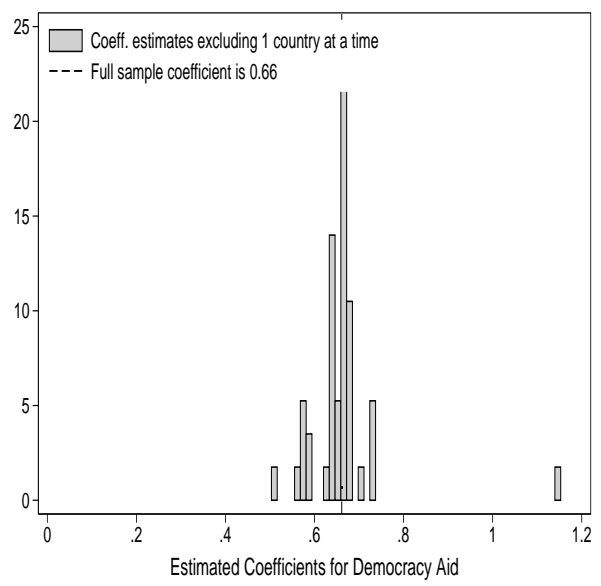

Figure B-1: Distribution of estimates from IV probit models for Economic aid (Table 1, column 3) and Democracy aid (Table 2, column 6) when excluding one country at a time from the sample. 


\section{Appendix C: Identification strategy}

\section{Constructing the "outside" instruments}

To construct the "outside" excluded instruments, we use a donor characteristic $V_{d, t}^{a}$, which is one of two donor variables (Inflation or WiP, denoted by the superscript $a$ ), and which varies by donor $d$ and year $t$. For each recipient $i$ and donor $d$ in each year $t$, we multiply $V_{d, t}^{a}$ by the inverted geographic distance in kilometers (denoted by $k_{d, i}$ ) between donor $d$ and recipient $i$ : $V_{d, t} \times k_{d, i}$. Then we sum these to create the instrument, for each donor characteristic $a \in($ Inflation, WiP)

$$
Z_{i, t}^{a}=\sum_{d}\left(V_{d, t}^{a} \times k_{d, i}\right)
$$

For the binary dependent variable model (dropping the superscript $a$ on $Z$ ), the resulting specification in an "exactly" identified equation would be:

$$
\begin{aligned}
\operatorname{Pr}\left(Y_{t}=1 \mid Y_{t-1}=0\right) & =\widehat{A i d_{i, t}}+X_{i, t}+\zeta_{i, t}+\epsilon_{i, t}^{1} \\
A i d_{i, t} & =Z_{i, t}+X_{i, t}+\zeta_{i, t}+\epsilon_{i, t}^{2}
\end{aligned}
$$

where $A i d_{i, t}$ and $Z_{i, t}$ are three-year lagged moving averages of aid and the instrument, $\widehat{A i d_{i, t}}$ is the predicted value of aid from the first stage, $X_{i, t}$ are control variables, and $\zeta_{i, t}$ are duration polynomials.

Figure C-1 shows the partial correlation between different categories of aid and the two outside excluded instruments (Inflation and WiP), in the full sample. From these partial correlation plots, we can see that donor inflation is strongly and positively correlated with economic aid but weakly and negatively correlated with democracy aid. We find just the opposite pattern for women in parliament: $W i P$ is strongly and positively correlated with democracy aid but negatively correlated with economic aid. One possible explanation for these patterns could be that during times of inflation, donors are likely to focus the aid portfolio on critical development sectors - at the expense of democracy promotion - while more women in parliament might shift aid portfolios towards more democracy-oriented sectors. Based on these partial correlations and expectations that each outside instrument should be positively correlated with foreign aid, we employ Inflation as an excluded instrument for economic aid and WiP as an excluded instrument for democracy aid.

Finally, we note that there are some potential outliers in the first stage partial correlation between Inflation and Economic aid, as observed in the lower right corner of the upper left panel of Figure C-1. These three observations come from South Africa prior to the multiparty transition in 1994 (South Africa received less Western foreign aid from fewer OECD donor countries). This helps explains the low partial correlation between Inflation and Economic aid in the transition sample used in Table 1 of the main text. Dropping South Africa and using Inflation in a just identified equation (i.e. without the Lewbel instruments) yields a strong first-stage (partial) correlation between Inflation and Economic aid (F-statistic= 17.8), with similar second stage results.

\section{Identification with the Lewbel approach}

The approach proposed by Lewbel (2012) identifies a two-equation model by using the presence of heteroskedasticity (or a correlation between residuals and some exogenous covariates) in the "first- 


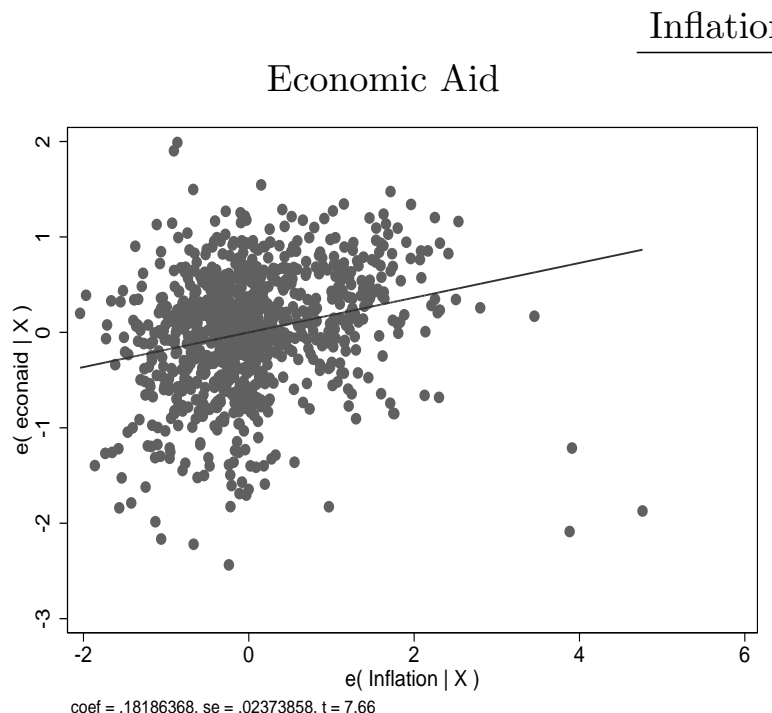

Democracy Aid

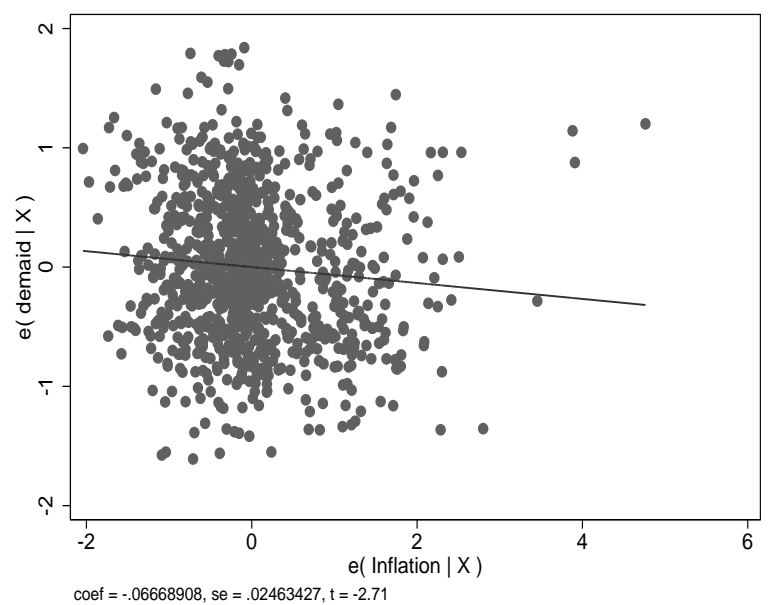

Women in Parliament (donor)

Economic aid

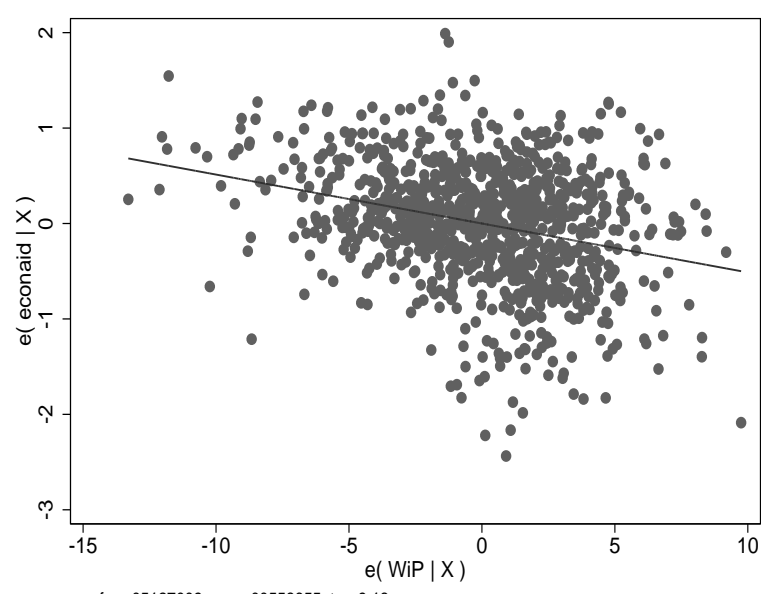

coef $=-.05127009, \mathrm{se}=.00558655, \mathrm{t}=-9.18$
Democracy aid

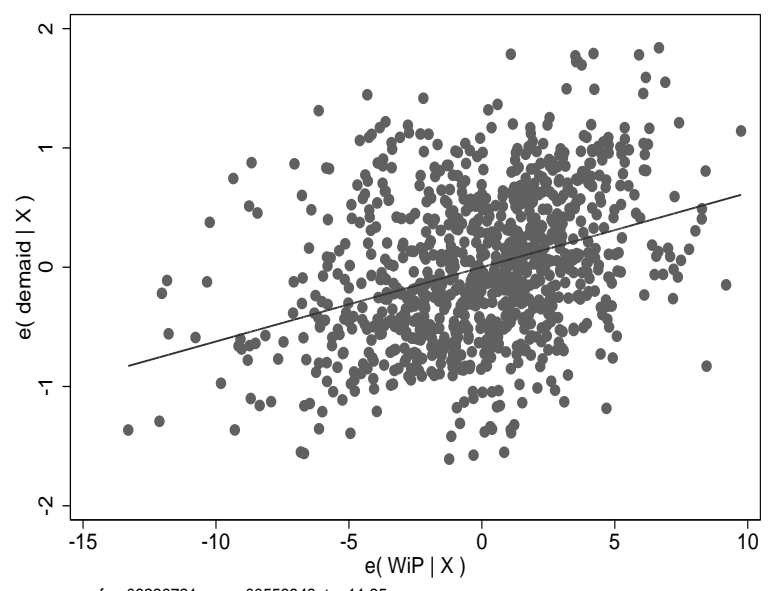

coef $=.06226721, \mathrm{se}=.00553343, \mathrm{t}=11.25$

Figure C-1: Partial correlations for "outside" instruments and foreign aid. 
stage" linear regression. Identification exploits the fact that covariance between the "first-stage" errors and the exogenous variables $(X)$ is not necessarily zero but rather heteroskedastic. Consider the following two-equation model for our application:

$$
\begin{aligned}
Y_{1} & =\beta_{1} X+\gamma_{1} A i d+\epsilon^{1} \\
A i d & =\beta_{2} X+\gamma_{2} Z+\epsilon^{2}
\end{aligned}
$$

The main outcome variable of interest $\left(Y_{1}\right)$ is a function of covariates $(X)$ and $(A i d)$, which is endogenous (mismeasured). If $Z$ is correlated with aid but unrelated to $Y_{1}$, then $Z$ may used as an "outside" excluded instrument to generate predicted values of Aid. If, however, the $\operatorname{cov}\left(X, \epsilon_{2}^{2}\right) \neq$ 0 , the "first stage" residuals can be exploited as an "inside" excluded instrument. Because the heteroskedasticity arises from the "first stage", this does not threaten inferences from the estimate of $\gamma_{1}$. In practice, the construction of an "internal," model-based excluded instrument is the following: (1) calculated the residual from a "first-stage" regression $\left(\epsilon_{i, t}\right) ;(2)$ calculate the in-sample deviation from the mean for each independent variable in the first stage regression $\left(X_{i, t},-\mu_{X}\right)$; and finally (3) multiply the two: $I=\epsilon_{i, t} \times\left(X_{i, t},-\mu_{X}\right)$. Note that we can construct one "inside" instrument from each of the independent variables in the first stage equation. Throughout the manuscript, we refer to these "internal" excluded instruments as "Lewbel" instruments.

Since this approach requires the presence of heteroskedastic errors in the first-stage equation, we examine the main model (for each type of aid) from each of the reported tests in the manuscript. As Lewbel (2012) notes, it is easy to examine the scale-related heteroskedasticity with a BreuschPagan type test in an OLS context, such as the first-stage equations in the present application. Table C-1 reports these. The null in these tests is that the variance is constant (i.e. there is no heteroskedasticity). Thus a large test statistic $\left(\chi^{2}\right)$ indicates a rejection of the null, or the presence of heteroskedasticity; and this means the Lewbel approach is likely to enhance the efficiency of the IV estimator. When the test statistic is small, indicating little heteroskedasticity, including "Lewbel" instruments is unlikely to improve model efficiency.

Table C-1: Heteroskedasticity in the first-stage regressions

\begin{tabular}{clcc}
\hline \hline \multicolumn{1}{c}{ Model } & Aid type & $\chi^{2}$ & p-value \\
\hline Table 1, column 2 & Economic & 86.1 & 0.000 \\
Table 1, column 5 & Democracy & 11.2 & 0.001 \\
Table 2, column 2 & Economic & 0.4 & 0.528 \\
Table 2, column 5 & Democracy & 8.8 & 0.003 \\
Table 3, column 2 & Economic & 12.2 & 0.001 \\
Table 3, column 5 & Democracy & 1.2 & 0.281 \\
Table 4, column 2 & Economic & 0.06 & 0.804 \\
Table 4, column 5 & Democracy & 0.56 & 0.455 \\
\hline
\end{tabular}

The "inside" instruments are only likely to increase the efficiency of the IV estimator in four of the eight main models where the test statistic is large. This same result can be seen by looking at the F-statistic for all excluded instruments for each model and comparing it with the F-statistic for $Z$ (the outside instrument) only. For example, the complete instrument set in column 2 of Table 
1 has an F-statistic of 22.6, but the F-statistic for Inflation is only 9.5. ${ }^{1}$ This indicates that the "inside" instruments substantially help the "explain" economic aid in that sample. This is another way of showing the same information contained in the large $\chi^{2}$ statistic in the first row of Table C-1. In contrast, the "inside" instruments do little to explain economic aid in the samples used in Tables 2 and 4. Indeed the F-statistics for all excluded instruments in model 2 is not appreciably larger than the F-statistic for $Z$ only. In fact, for the model in Table 2 column 2, the F-statistic for all excluded instruments is lower than the F-statistic for $Z$ only, meaning that adding "inside" instruments hurts efficiency in the IV estimator. Again, this information is also reflected in the very low $\chi^{2}$ statistic in the third row of Table C- 1 .

To provide a consistent estimator across all models and specifications in the main text and robustness checks, we include the "inside" (or "Lewbel") instruments in all reported tests. However, Table C-2 reports results from each of the main models where there is very little heteroskedasticity present in the first stage errors (implying that the "Lewbel" instruments are not very useful). These results parallel those reported in the main text, but the IV estimator is more efficient in the two models, reflected in a larger F-statistic than when using the "Lewbel" instruments as well.

Table C-2: Results without Lewbel instruments

\begin{tabular}{|c|c|c|c|c|c|c|}
\hline Model & $\begin{array}{c}\text { Table } 2 \\
\text { column } 2 \\
\end{array}$ & $\begin{array}{c}\text { Table } 3 \\
\text { column } 5\end{array}$ & $\begin{array}{c}\text { Table } 4 \\
\text { column } 2\end{array}$ & $\begin{array}{c}\text { Table } 4 \\
\text { column } 3\end{array}$ & $\begin{array}{c}\text { Table } 4 \\
\text { column } 5\end{array}$ & $\begin{array}{c}\text { Table } 5 \\
\text { column } 6\end{array}$ \\
\hline Dependent variable & $\begin{array}{c}\text { Mulitparty } \\
\text { failure }\end{array}$ & $\begin{array}{c}\text { Electoral } \\
\text { misconduct }\end{array}$ & \multicolumn{4}{|c|}{ Opposition vote share } \\
\hline Economic aid & $\begin{array}{l}-0.037 \\
(0.04)\end{array}$ & & $\begin{array}{c}-1.657^{* *} \\
(0.80)\end{array}$ & $\begin{array}{l}-0.848 \\
(0.79)\end{array}$ & & \\
\hline Democracy aid & & $\begin{array}{c}-0.303^{* *} \\
(0.14)\end{array}$ & & & $\begin{array}{c}2.373^{* *} \\
(1.02)\end{array}$ & $\begin{array}{l}0.963 \\
(0.66)\end{array}$ \\
\hline Log GDP pc & $\begin{array}{l}0.012 \\
(0.01)\end{array}$ & $\begin{array}{l}-0.051 \\
(0.06)\end{array}$ & $\begin{array}{l}0.052 \\
(0.25)\end{array}$ & $\begin{array}{l}-0.153 \\
(0.15)\end{array}$ & $\begin{array}{l}0.133 \\
(0.31)\end{array}$ & $\begin{array}{l}-0.078 \\
(0.18)\end{array}$ \\
\hline Log population & $\begin{array}{l}-0.007 \\
(0.02)\end{array}$ & $\begin{array}{l}0.005 \\
(0.05)\end{array}$ & $\begin{array}{c}-0.594^{*} \\
(0.31)\end{array}$ & $\begin{array}{c}-0.426^{*} \\
(0.25)\end{array}$ & $\begin{array}{l}0.294 \\
(0.20)\end{array}$ & $\begin{array}{l}0.036 \\
(0.14)\end{array}$ \\
\hline Civil war & $\begin{array}{l}-0.069 \\
(0.06)\end{array}$ & & & & & \\
\hline IMF program & & $\begin{array}{l}0.047 \\
(0.14)\end{array}$ & $\begin{array}{l}0.617 \\
(0.50)\end{array}$ & $\begin{array}{l}0.492 \\
(0.31)\end{array}$ & $\begin{array}{l}-0.814 \\
(0.61)\end{array}$ & $\begin{array}{r}-0.230 \\
(0.31)\end{array}$ \\
\hline First multiparty election & & $\begin{array}{l}0.055 \\
(0.12)\end{array}$ & & & & \\
\hline Monitor & & $\begin{array}{l}-0.067 \\
(0.14)\end{array}$ & & & & \\
\hline Growth & & & $\begin{array}{r}-0.040 \\
(0.04)\end{array}$ & $\begin{array}{l}-0.002 \\
(0.02)\end{array}$ & $\begin{array}{c}-0.058^{* *} \\
(0.03)\end{array}$ & $\begin{array}{l}-0.021 \\
(0.02)\end{array}$ \\
\hline (Intercept) & $\begin{array}{c}1.054^{* *} \\
(0.29) \\
\end{array}$ & $\begin{array}{l}1.171 \\
(0.74) \\
\end{array}$ & $\begin{array}{c}10.140^{*} \\
(5.51) \\
\end{array}$ & $\begin{array}{l}7.362 \\
(4.52) \\
\end{array}$ & $\begin{array}{r}-6.808 \\
(4.27) \\
\end{array}$ & $\begin{array}{r}-1.362 \\
(2.98) \\
\end{array}$ \\
\hline Observations & 583 & 170 & 84 & 70 & 84 & 70 \\
\hline F-stat & 56.4 & 36.2 & 8.4 & 5.7 & 7.4 & 3.6 \\
\hline
\end{tabular}

${ }^{*} \mathrm{p}<0.10 ;{ }^{* *} \mathrm{p}<0.05$. IV linear models with clustered standard errors in parentheses. Duration polynomials not reported in column 1 .

${ }^{1}$ This latter F-statistic reflects the partial correlation between Inflation and economic aid, conditional on the covariates and the "inside" instruments. 


\section{Exploring the exclusion restriction of the "outside" instruments}

\section{Overidentification tests}

A method for exploring the strength of exclusion assumption is a test of overidentification (Baum, Schaffer and Stillman, 2003). This approach assumes that the "inside" instruments are valid - in the sense of meeting the exclusion restriction - and tests whether the "outside" instruments are orthogonal to the error process in the outcome equation. For each model in the main text, we report the C-statistic, which tests whether "outside" instrument is orthogonal to the errors in the outcome equation, conditional on the "inside" instruments being valid. In all models, the p-value of the C-statistic is greater than the conventional cut-point of 0.10 , suggesting that Inflation and WiP are valid excluded instruments.

\section{Alternative channel of influence}

While the C-statistic provides some information on the exclusion restriction for the "outside" instruments, it still assumes some valid excluded instruments to conduct the overidentification tests. Theoretically, there may be alternative factors that are correlated with (even if not causally related to) donor inflation and women in parliament. And these additional, unmodeled (perhaps unobserved) factors may be causally related to the outcomes of interest. To explore this possibility, we examine the partial correlation (i.e. conditional on covariates) between the outside instruments and plausible alternative channels: trade; international and domestic non-governmental organizations; the stock of recipient-country migrants in donor countries; alliances with donors; and the number of international organizations to which the recipient government belongs.

We select these variables because they represent key areas of a country's foreign policy which could potentially be influenced by or correlated with female legislative representation or inflation. These areas include trade, immigration, membership in international organizations, nongovernmental organizations, and security. We do not have theoretical priors about the direction through which an increase in the number of women in parliament might influence these foreign policy areas. We thus focus our attention on the variables' statistical association with our instruments.

Measures and data sources

- Trade: The data for trade come from the IMF's DOT database. We focus on trade, measured as a logged sum of exports and imports from the aid-receiving country and donor countries in the sample. It could be that female legislators are systematically more/less likely to push for trade increase with democratizing countries than their male counterpart. This leads to the conjecture that an increase in women in parliament affects democratic change in the recipient country through the trade channel.

- Immigration: The data for immigration are from the OECD's International Migration Databse. We utilize a migrant stock measure, which captures the annual stock of people whose country of origin is the aid-receiving African country and who currently reside in an OECD donor country. It could be that female legislators are systematically more/less likely than their male counterparts to lobby for increased immigration flows from countries where democratic change occurs. This could imply that women in parliament affects democratic change in the aid receiving country through the channel of immigration. 
- Membership in international organizations: We use IO membership data to capture "soft" diplomacy. The data for IO membership come from Pevehouse 2006. We create a count of international organizations to whom aid receipient countries belong as members. If women are more/less likely to promote integration through international institutions, then democratic change in the recipient country could be affected through the channel of diplomacy.

- Alliances: We use membership in security alliances to capture the security channel. The data for alliance membership come from the Correlates of War Project. We create a count of alliances that are shared between aid recipient countries and OECD countries in the donor sample. If women are more/less likely than men to promote security relations through military alliances then democratic change in the recipient country could be affected through the security channel

- IGO and NGO Presence: We use the logged number of international and local non-governmental organizations in aid-receiving countries as proxy for a donor governments' level of partnership with international and local NGOs. The data are drawn from the Yearbook of International Organizations.

Table 3: Bivariate correlations

\begin{tabular}{lcc}
\hline \hline Alternative & & Women in \\
Channels & Inflation & Parliament \\
\hline Trade & -0.012 & 0.234 \\
International NGOs & -0.004 & -0.225 \\
Domestic NGOs & 0.002 & -0.203 \\
Migrants & 0.068 & 0.172 \\
Alliance & -0.010 & 0.004 \\
IO membership & -0.302 & 0.327 \\
\hline \hline
\end{tabular}

If the outside instruments are correlated with these factors, which might be causally related to the outcome variable, then the exclusion assumption is weaker. The partial correlation plots in Figure C-2 show that three of these variables are (partially) correlated with Inflation: trade; migrant stock; and IO membership. For trade and IO membership the correlation with Inflation is driven in large part by a handful of outliers: recipient countries with low trade and membership relatively few IOs. None of the proxies for alternative channels, however, are (partially) correlated with women in parliament. Thus there is little empirical connection between the WiP and these alternative channels. In Appendix B, we report robustness tests in which the specification adds each of these variables as a control. In each of these tests, the main reported result holds.

\section{Treating the "outside" instruments as "plausibly" exogenous}

In this section, we relax the exogeneity assumption to assess how doing so influences the estimate of interest. In the spirit of treating the outside instruments as "plausibly exogenous", we examine whether inference from the reported tests wiil still be valid even if these variables $(Z)$ are weakly related to the outcome. Conley, Hansen and Rossi (2012) introduce an approach that allows researchers to assess how the estimate of interest in an outcome equation changes as an excluded 
Inflation
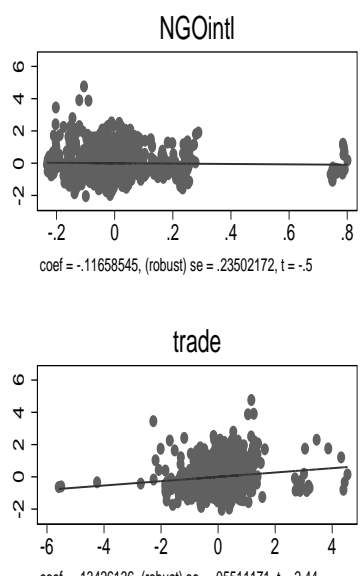

coef $=.13426136$, (robust) $s e=.05511171, \mathrm{t}=2.44$

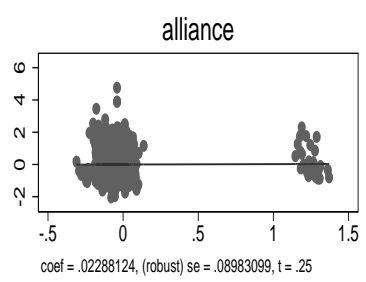

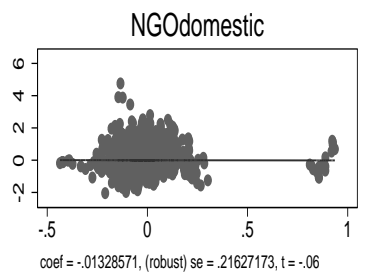
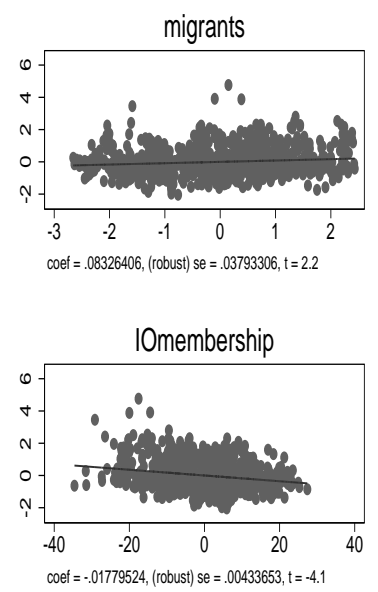

Women in parliament
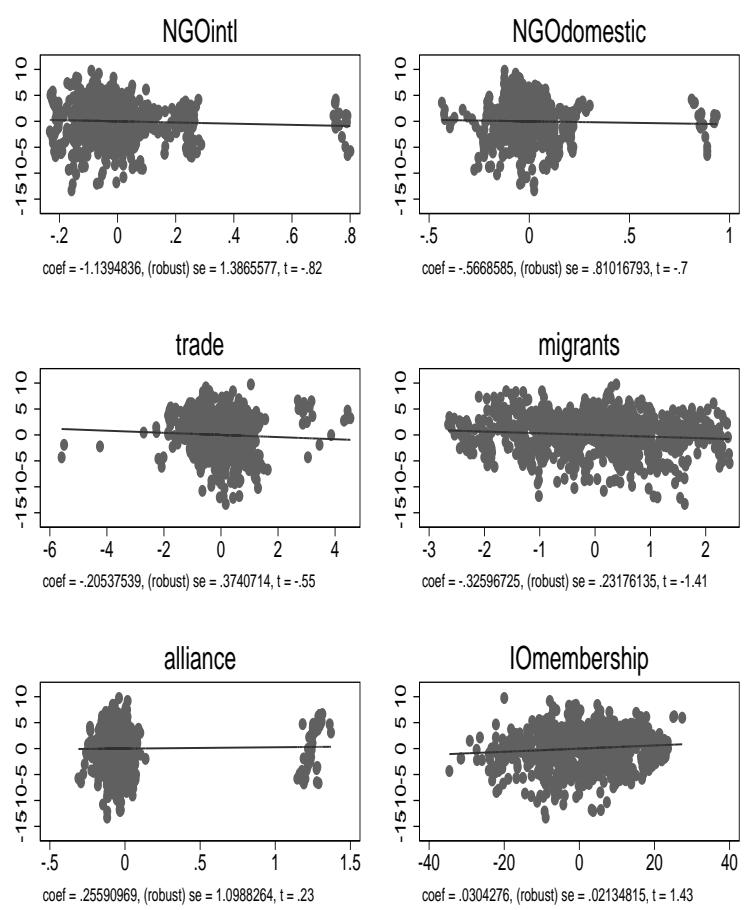

Figure C-2: Partial correlation between outside instruments and alternative channels. 
instrument becomes more highly correlated with the errors in the outcome equation. Consider the following equation, where $Y$ is the outcome variable, $X$ are (potentially endogenous) covariates and $Z$ is a (potentially) excluded instrument.

$$
Y=\beta X+\gamma Z+\epsilon
$$

The exogeneity restriction amounts to assuming that $\gamma=0$. Conley, Hansen and Rossi (2012) examine several approaches to relaxing this assumption by allowing $\gamma \neq 0$ and assessing how do so influences estimates of $\beta$.

In our application, we use the unified confidence interval approach, which makes no prior assumption about the distribution of $\gamma$ but only specifies the possible values for $\gamma$. As Conley, Hansen and Rossi (2012) show, this is the most conservative approach insofar as making assumptions about the distribution reduces the coverage area, thus narrowing the errors bands for the estimate of interest. $^{2}$ We adopt this approach because we do not have a theoretically informed prior belief about the possible causal relationship between donor inflation (and female parliamentary representation) and political change in African aid recipient countries. ${ }^{3}$ We do, however, have an estimate of $\gamma$ from the reduced-form equation, which we use as a "plausible" upper bound for $\gamma$. That is, if the outside instruments are not completely exogenous, then the worst case scenario is that $\gamma$ is approximately as large as the reduced-form estimate of $\gamma$.

Figure C-3 shows how the estimates for Economic aid and Democracy aid change (for the models reported in Table 1, column 2 and Table 2, column 5, respectively) as we vary $\gamma$ from zero ("exogenous") up to the reduced form estimate of $\gamma$. The differing horizontal scales in each panel of the figure reflect the fact that the estimates of the reduced-form coefficients differ for each model. In the multiparty transition model, the reduced-form estimate of $\gamma_{\text {Inflation }}$ is 0.038 , while the reduced-form estimate of $\gamma_{W i P}$ in the multiparty failure model is 0.0037 . We might think of these as plausible upper bounds for the extent to which the outside instrument is not exogenous but simply "plausibly exogenous."

When $\gamma_{\text {Inflation }}$ equals zero, the left panel depicts the estimate of Economic aid, assuming a perfectly exogenous outside instrument. As $\gamma_{\text {Inflation }}$ increases, this assumption is less plausible. The left panel shows that even if $\gamma_{\text {Inflation }}$ exceeds the reduced-form estimate, then the coverage area for the estimate of Economic aid does not contain zero. The right panel of C-3 shows that the exogeneity assumption must be stronger for WiP for the estimate of Democracy aid to remain valid: the error band contains zero once $\gamma_{W i P}$ reaches about 0.0006 - or about one-sixth of the size of the reduced-form estimate.

We reiterate that these tests are not tests of instrument exogeneity, but rather simulations of the estimate of interest if we assume that the exogeneity assumption is only "plausible" and not "perfect." These tests do not tell us whether we have a "weak" instrument but rather conservatively assess how the causal estimates for foreign aid would change if the "outside" excluded instruments

\footnotetext{
${ }^{2}$ Conley, Hansen and Rossi $(2012,260)$ note that "[i]nterval estimates for $\beta$, the treatment parameter of interest, can be obtained conditional on any potential value of $\gamma$. Taking the union of these interval estimates across different $\gamma$ values provides a conservative (in terms of coverage) interval estimate for $\beta$. A virtue of this method is that it requires only specification of a range of plausible values for $\beta$ without requiring complete specification of a prior distribution. Its chief drawback is that the resulting interval estimates may be wide."

${ }^{3}$ We set the priors on the "Lewbel" instruments to zero, thus assuming they are exogenous.
} 

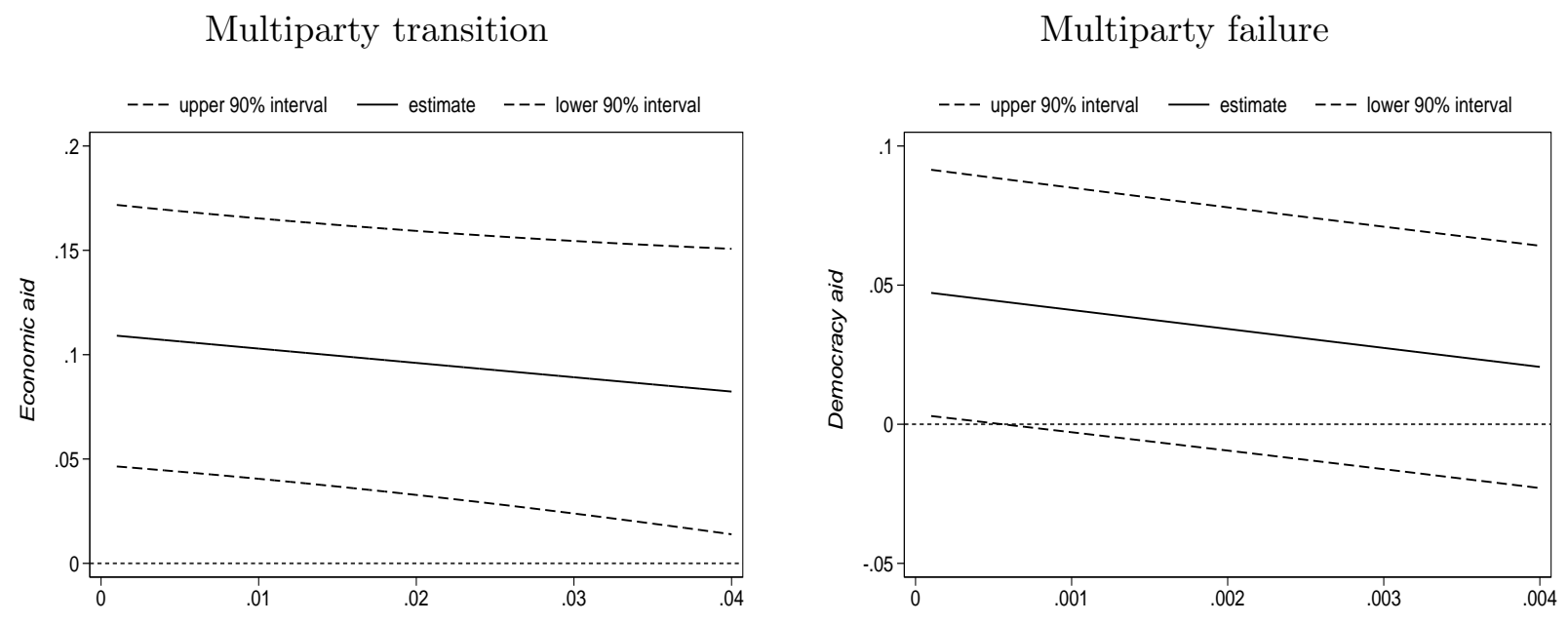

Figure C-3: Coefficient estimates and 90 percent Unified Confidence Intervals. Estimates for models reported in Table 1, column 2 (multiparty transition) and Table 2, column 5 (multiparty failure).

are correlated with the errors in the outcome equation.

Finally, we find these tests informative when we consider them alongside the information in Figure C-2, which shows that some plausible alternative channels are correlated with Inflation but not with $W i P$. While the union of confidence intervals are not as robust for $W i P$, we believe that this external instrument is more likely to be plausibly exogenous in the first place, as evidenced by the partial correlation plots in the right panel of Figure C-2.

\section{Exploring possible heterogeneous treatment effects}

For the IV estimate to recover the average treatment effect of the treated, treatment assignment cannot be heterogeneous. In other words, if the instrument set is only correlated with foreign aid in part of the sample and not another, then the treatment - in this case, the excluded instrument set - is not homogenous and the reported estimates in the outcome equation will not reflect the average treatment effect.

One way to explore for hetereogenous treatment effects is to (randomly) divide the sample in half and estimate the first-stage equation in each sub-sample to see if the partial correlation between the instrument set and the endogenous (foreign aid) variable is present in each. If there is a strong correlation in both sub-samples, then this provides some evidence consistent with the homogenous treatment effect assumption.

For the samples in Tables 1 and 2 of the main text, we randomly split each into two (half) sub-samples. Then we estimate the first stage equation and report the F-statistic for the joint signficance of the excluded instrument set. The top panel of Table C-4 shows the F-stastics from this exercise. For each model, the (random) split-samples each yield F-statistics greater than 10.0. Next, we divide each sample by the median year; and again the F-statistics are large for each subsample in each model. The only F-statistic that is less than 10 is the one for the earlier years in the 
multiparty transition sample. (Note that the earlier sub-sample contains lagged aid information from the late 1980s.) Finally, when we split each sample geographically (roughly along northern versus southern parts of sub-Saharan Africa), the sub-samples again yield large F-statistics. This exercise suggests that, at least when we divide each of these samples in half, there is evidence of strong treatment assignment in each.

Table C-4: F-statistics from split samples

\begin{tabular}{cllc}
\hline \hline \multicolumn{1}{c}{ Model } & Aid type & F-stat 1 & F-stat 2 \\
\hline \hline & & \multicolumn{2}{c}{ Random sub-samples } \\
\cline { 3 - 4 } Table 1, column 2 & Economic & 11.7 & 15.6 \\
Table 2, column 5 & Democracy & 15.8 & 36.1 \\
& & \multicolumn{2}{c}{ Divide by year } \\
Table 1, column 2 & Economic & 30.1 & 9.1 \\
Table 2, column 5 & Democracy & 12.9 & 148.9 \\
& & \multicolumn{2}{c}{} \\
Table 1, column 2 & Economic & 27.1 & 17.6 \\
Table 2, column 5 & Democracy & 35.2 & 14.6 \\
\hline
\end{tabular}

\section{References}

Baum, Christopher F, Mark E Schaffer and Steven Stillman. 2003. "Instrumental variables and GMM: Estimation and testing." Stata Journal 3(1):1-31.

Burr, Millard and Robert Oakley Collins. 2003. Revolutionary Sudan: Hasan Al-Turabi and the Islamist State, 1989-2000. Vol. 90 Brill.

Clark, John F. 2003. "Foreign Intervention in the Civil War of the Congo Republic." A Journal of Opinion 26(1):31-36.

Conley, Timothy G, Christian B Hansen and Peter E Rossi. 2012. "Plausibly exogenous." Review of Economics and Statistics 94(1):260-272.

Daddieh, Cyril K. 2001. "Ethnicity and Recent Democratic Experiments in Africa." African Issues 26(1/2):14-19.

Debos, Marielle. 2008. "Fluid Loyalties in a Regional Crisis: Chadian Ex-Liberators in the Central African Republic." African Affairs 107(427):225-241.

Englebert, Pierre. 2003. Niger: Recent History. In Africa South of the Sahara, ed. Katharine Murison. Europa Publications.

Lewbel, Arthur. 2012. "Using heteroscedasticity to identify and estimate mismeasured and endogenous regressor models." Journal of Business 86 Economic Statistics 30(1). 
Malan, Mark. 2005. "Transitions With Minimal Assistance: Lessons from Guinea-Bissau?" KAIPTC Paper 5.

N'Diaye, Boubacar. 2006. "Mauritania, August 2005: Justice and democracy, or just another coup?" African Affairs 105(420):421-441.

N'Diaye, Boubacar. 2009. "To 'midwife' and abort a democracy: Mauritania's transition from military rule, 2005-2008." Journal of modern African studies 47(1):129-152.

Outram, Quentin. 2003. Liberia: Recent History. In Africa South of the Sahara, ed. Katharine Murison. Europa Publications.

Pazzanita, Anthony G. 2008. Historical dictionary of Mauritania. Vol. 110 Scarecrow Press.

Reno, William. 1999. Warlord Politics and African States. Boulder: Lynne Rienner Publishers.

Reyntjens, Filip. 2009. The great African war: Congo and regional geopolitics, 1996-2006. Cambridge University Press.

Saine, Abdoulaye. 2002. "Post-coup politics in The Gambia." Journal of Democracy 13(4):167-172. 